\title{
The Royal Portrait in the Het'um Lectionary (1286) and the Genealogy of Christ in the Art and Ideology of the Armenian Kingdom of Cilicia
}

\author{
Edda Vardanyan
}

In manuscript illuminations produced in the Armenian Kingdom of Cilicia, ${ }^{1}$ the establishment of the royal portrait as a genre and as an expression of royal ideology is linked to King Lewon II (r. 1271-1289), whose reign marked the apogee of this kingdom. Five portraits of Lewon have survived from the second half of the $13^{\text {th }}$ century, the earliest among them representing him as heir to the throne and the later ones as a sacred king. ${ }^{2}$ The last portrait of Lewon marking the end of his reign - appears in a lectionary of 1286, copied and illuminated on the order of his eldest son, Prince Het'um. ${ }^{3}$ Known as the Prince Het'um Lectionary, it is richly illustrated and has been the subject of several studies. $^{4}$

1 The Armenian Kingdom of Cilicia (formerly a principality) in south-eastern Anatolia was founded by Armenian refugees fleeing the Seljuk invasions of Greater Armenia. Throughout its existence, the kingdom was often allied with the various Crusader states of the Levant. Armenian Cilicia was an independent kingdom from 1080 until the fall of its capital Sis to the Mamluks in 1375. On the Armenian Kingdom of Cilicia and for further relevant bibliography, see: Levon Ter-Petrossian, Xačakirnerə ev Hayerə [The Crusaders and the Armenians], 2 vols (Yerevan, 2005/o7); Claude Mutafian, L'Arménie du Levant, XIe-XIVe siècles, 2 vols (Paris, 2012). Mss:Yerevan, Matenadaran, M8321 (fol. 15r), M979 (fol. 7 r);Jerusalem, Armenian Patriarchate, J266o (fol. 288r), J2563 (fol. 38or); London, British Library Or. 13993 (fol. 9v). See: Sirarpie Der Nersessian, Miniature Painting in the Armenian Kingdom of Cilicia from the Twelfth to the Fourteenth Century, 2 vols (Dumbarton Oaks Studies, 31) (Washington, D.C., 1993), 1:154-58, 2:figs. 639-43; Levon Chookaszian, "The Five Portraits of King Levon II (1270-89) of Armenian Kingdom of Cilicia and their Connections to the Art of Mediterranean Area," in Medioevo: immagini e ideologie, Atti del Convegno internazoinale di studi, Parma, 23-27 settembre 2002, ed. Arturo Carlo Quintavalle (Milano, 2005), pp. 129-37; Gohar Grigoryan, Royal Images of the Armenian Kingdom of Cilicia (1198-1375) in the Context of Mediterranean Intercultural Exchange, Ph.D. (University of Fribourg, Switzerland, 2017); Mutafian, L'Arménie du Levant, 2:figs. 189-93.

3 Yerevan, Matenadaran, M979, fol. 7 r.

4 Der Nersessian, Miniature Painting, 1:157-58; Irina Drampian, Lectionary of King Hetum II. Armenian illustrated codex of 1286 A.D. (Yerevan, 2004); Ioanna Rapti, "Image et liturgie à la cour de Cilicie: Le lectionnaire du prince Het'um (Matenadaran MS 979)," Monuments et Mémoires de la Fondation Eugène Piot 87 (2008), 105-42.

(C) EDDA VARDANYAN, 2022 | DOI:10.1163/9789004511583_005

This is an open access chapter distributed under the terms of the CC BY-NC 4.o license vardanyan - 9789004511583 Downloaded from Brill.come4/26/2023 08:51:23AM 
On the opening page of this manuscript, we find a depiction of the royal family arranged in a family tree (figures. 3.1, 3.11). Six figures, the uppermost pair each with a crown and halo, are inscribed in a tree structure in the right margin of the page. According to general opinion, this marginal decoration represents the royal family, with the reigning King Lewon II at the top of the tree. This composition is often compared with the Tree of Jesse, a symbolic representation of the genealogy of Christ that originates in the prophet Isaiah's foretelling of the birth of the Messiah from the root of Jesse, the father of King David (Isa. 11:1-2). ${ }^{5}$ In the Armenian Kingdom of Cilicia, the theme of the genealogy of Christ was crucial in affirming and exalting the divine right of the king. Similarly, as is well known, the portrait of the king - the pictorial representation of his sacred person - is foremost a visual expression of royal ideology. Therefore, in aiming to better understand the motivations behind the creation of the royal portrait in the Het'um Lectionary, this paper explores the significance of the genealogy of Christ in the kingdom's art and ideology.

The first Armenian manuscript to contain portraits of the ancestors of Christ is the Gospel of Skewra, produced in $1198 .^{6}$ That same year, Lewon of the Rubenid family was crowned King Lewon I. ${ }^{7}$ Politically, his coronation solved a number of vital issues related to the involvement of the Armenian Kingdom of Cilicia in Western European ambitions in the Eastern Mediterranean, strengthening and expanding the borders of the kingdom and placing it on an equal footing with the Crusaders States. Lewon's main task was the restoration and international recognition of Armenian statehood. As a result of long diplomatic negotiations, the Armenian Kingdom of Cilicia was recognized simultaneously by the Holy Roman and Byzantine emperors as well as by the pope. ${ }^{8}$ Prince

5 Der Nersessian, Miniature Painting, 1:158; Rapti, "Image et liturgie à la cour de Cilicie," p. 113.

6 Varsovie, Biblioteka Narodowa, Akc. 1768o. See: Der Nersessian, Miniature Painting, 1:135, 2:figs. 30-31, 34-35, 38-41; Das Lemberger Evangeliar: eine wiederentdeckte armenische Bilderhandschrift des 12.Jahrhunderts, eds. Günter Prinzing, and Andrea Schmidt (Wiesbaden, 1997).

7 Mutafian, L'Arménie du Levant, 1:330-33.

8 The royal investiture of Lewon was recognized by the Holy Roman Emperor Henry vi, the Byzantine emperor Alexis III, and Pope Celestin III, see:Ter-Petrossian, The Crusaders, 2:18696; Mutafian, L'Arménie du Levant, 1:91-101; Levon I. Ein Armenischer König im Staufischen Outremer, eds. Christian Philipsen, Thomas Bauer-Friedrich, and Ulf Dräger (Halle, 2019). 
Lewon was thus proclaimed the first Cilician king, Lewon I. ${ }^{9}$ His coronation took place, with great pomp, on 6 January, the feast of the Nativity and the Epiphany in the Armenian Church.

More than once, the dating of the Gospel of Skewra and the superior quality of its execution have led researchers to suspect that it was produced in connection with the coronation of Lewon. ${ }^{10}$ However, due to the lack of historical data, this hypothesis has not been confirmed. ${ }^{11}$ Based on a close analysis of the Gospel of Skewra, which will then inform my analysis of the Het'um Lectionary, I believe that its iconographic program makes an obvious allusion to the coronation of the king in that it symbolically reflects the solemnities of the feast of the Epiphany celebrated by the Armenian Church on 6 January, the day chosen for the coronation of Lewon I. ${ }^{12}$

The feast of the Epiphany is important in the dogma of the Armenian Church, since it brings together the celebrations of the birth and baptism of Christ. ${ }^{13}$ After the Eucharistic service, the rite of the Blessing of Water is performed: the Holy Chrism (miwron) is poured into a basin symbolizing the Jordan River, in memory of the descent of the Holy Spirit on Jesus Christ at the time of his baptism. The coronation of Lewon I took on greater symbolic meaning through its connection to this significant feast. The anointing was the most important moment in the ceremony, articulating its symbolic association with the baptism of Christ and manifesting the concept of sacred kingship. The coronation of the king, performed on the day of the Epiphany, thus functioned as a form of 'epiphany' with respect to ideas about the divine origin of power.

As king, Lewon received many official titles confirming his legitimacy: 'King of all Armenians' (Rex omnium Armenorum) and 'King of Armenia by the will of God' (Dei gratia Rex Armenie), among others: Ter-Petrossian, The Crusaders, 2:196-201; Mutafian, L'Arménie du Levant, 1:420-25; Vahe T'orosyan, "Kilikiayi Hayoc' t'agavor Lewon Mecagorci t'agadrman xndri šurj” [On the Crowning of Lewon the Great, Armenian King of Cilicia], Ëmiacin 12 (2016), 84-112, esp. 105-07.

10 Günter Prinzing, "Zur Bedeutung und Geschichte des Lemberger Evangeliars," in Das Lemberger Evangeliar, eds. Prinzing, and Schmidt, pp. 11-26, esp. pp. 20-21; Günter Prinzing, and Helen C. Evans, "The L'viv Gospels," in The Glory of Byzantium: Art and Culture of the Middle Byzantine Era, A.D. 843-1261, eds. Helen C. Evans, and William D. Wixom (New York, 1997), pp. 361-62; Andrea Schmidt, "L'Évangile de Lemberg: un itinéraire rocambolesque," in Arménie. La magie de l'écrit, ed. Claude Mutafian (Paris, 2007), pp. 26o-63.

11 See: Anton von Euw, "Das Lemberger Evangeliar als Kunstwerk," in Das Lemberger Evangeliar, eds. Prinzing, and Schmidt, pp. 39-92, esp. p. 42.

12 A study of the illumination of the Gospel of Skewra and its relationship to royal ideology is currently underway by the author.

13 Charles Renoux, Le Lectionnaire de Jérusalem en Arménie: Le Čašoc' 1. Introduction et liste des manuscrits, PO 44/4, n. 200 (1989), pp. 428-33. 
During the years of Lewon I's reign, 6 January was celebrated not only as the feast of the Epiphany but also as a day of commemoration for his coronation. ${ }^{14}$

This is a vast subject and requires a more detailed treatment than I am able to carry out in this article. I will therefore limit myself to presenting a sketch of the most important issues. The main message of the illuminations of the Gospel of Skewra pertains to the advent of the Messiah. The iconographic program thus emphasizes the meaning of the term 'epiphany', with the illuminations symbolically reflecting the mystery of the Epiphany, as celebrated in its feast; they symbolize the manifestation of God. These miniatures, likewise, allude to the coronation ceremony of Lewon I. Viewed through the lens of a theology of power, they herald the advent of the 'anointed one' and simultaneously of Lewon's newly established worldly power.

For Lewon, the important thing was to confirm the legitimacy of his power, which is to say, to become the undisputed master of his country. He could achieve this only by being anointed, since only the anointed king could not be dethroned. ${ }^{15}$ In the 126os, this principle was legally codified by Smbat Sparapet (known as 'the Constable'): since the king - like the biblical kings before him is anointed by God, only God can revoke him. ${ }^{16}$ The anointing of Lewon at the time of his coronation therefore held great political significance. ${ }^{17}$

Within the iconographic program of the Gospel of Skewra, the representation of the genealogy of Christ encapsulates this concept of sacred kingship. It appears as a marginal miniature on the opening page of the Gospel of Matthew (Figure. 3.2) and consists of five medallions containing portraits of

14 Wilbrand von Oldenburg, who was hosted by Lewon I in 1212 and attended the feast, was amazed by the solemn pomp. He describes his impressions as follows: "We came to Sis on the Feast of the Appearance of the Lord, which the Armenians call the Day of the Baptism of Christ. That day, the king had invited us to his feast." He goes on to describe the Blessing of Water by the river. The king, riding a handsome steed, advanced at the head, accompanied by his entourage, members of the court, clergymen led by the archbishop, and soldiers carrying festive banners: "The audience greeted the king with an extraordinarily strong cheer: 'Sacred King.' When the river symbolizing the Jordan was blessed with the cross, the king and his entourage sprinkled water with loud acclamations. Marc Delpech, and Jean-Claude Voisin, "La mission en Cilicie de Wilbrand von Oldenburg en 1211-1212. Journal de route de Wilbrand," Mélanges de l'Université Saint-Joseph 56 (1999-2003), 291346, esp. 323-24.

15 Ter-Petrossian, The Crusaders, 2:184-85.

16 Ibid., 2:42.

17 The anointing of the Cilician kings with Holy Chrism is attested both in the ordo of the coronation and elsewhere. See: Derenik Davt'yan, Tagavorōrhnek'i kanona hay eketec'um [The Ordo of Coronation in the Armenian Church], Ph.D. for Vardapet ecclesiastical title (Holy See of Ë̌miacin, 2000), p. 80. 
Christ Emmanuel, King David, and the patriarchs Abraham, Isaac, and Jacob. The upper three medallions correspond to the first verse of the Gospel, which is written on this page: "The book of generations of Jesus Christ, son of David, son of Abraham" (Matt. 1:1). The genealogy itself - "Abraham begat Isaac, Isaac begat Jacob," etc. - begins on the next folio and is not accompanied by any illustrations.

The image that opens onto the Gospel of Matthew is not an abridged illustration of Matthew's genealogy. Rather, the selection of ancestors privileges King David (the biblical model for the anointed king) and the first three patriarchs elected by God (Heb. 11:8-21). All four are specifically mentioned as God's elect in the ordo for the coronation, appearing at the most important moment of the rite, namely in the prayer that immediately follows the anointing of the king with Holy Chrism. This passage from the ordo describes how the catholicos first anoints the king's head, chest, back, and arms by making the sign of the Cross. Then, he says a prayer that mentions the anointing of David by Samuel: this anointing is compared to that of the king. The prayer also references the patriarchs Abraham, Isaac, and Jacob in relation to the benefits obtained through the grace of the Holy Spirit. ${ }^{18}$

It is useful to further trace how the elements of the opening page of the Gospel of Matthew and their interrelation reflect the feast of the Epiphany and the concomitant rite of the coronation. The ordo's mention of the anointing resonates in the double portrait of Christ Emmanuel on the page as well as in the liturgical vase filled with water, which appears under the feet of the angel forming the initial. The image of Christ Emmanuel is symbolic of the action of the Holy Spirit; in Armenian manuscript illumination generally, this image is therefore employed in cases involving the communion of grace of the Holy Spirit, whether the Incarnation or the baptism of Christ. Consequently, it also becomes a symbol of the coronation or of consecration with the Holy Chrism, ${ }^{19}$ and it is in this context that Christ Emmanuel appears in the headpiece of the Gospel of Matthew. It unites the ideas of the two advents: on the one hand, that of Christ (i.e. the 'anointed one'

18 Davt'yan, The Ordo of Coronation in the Armenian Church, p. 8 o.

19 The illustrations of the ritual books prove this hypothesis. We find this image illustrating the canon of the ordination of priests by anointing, in the ordination book executed in 1248 at Skewra Monastery (Venice, Armenian Mekhitarist Congregation in San Lazzaro, V1657/1440, fol. 15r), as well as on the opening page of the canon of the Holy Chrism benediction in the ritual book of 1461 (Yerevan, Matenadaran, M4997, fol. 76v), see: Edda Vardanyan, "Un Maštoc' d'ordination et de sacre royal du XVe siècle," Revue des Études Arméniennes 29 (2003-04), 167-233, esp. 193-95. 
of God), the Messiah from the genealogy of God's elect, and, on the other, of the anointed king, as God's elect. The liturgical vase of water, a motif that can only be found in this manuscript, must allude to the rite of the Blessing of Water. ${ }^{20}$ This connection is further emphasized by the fact that the angel, lightly touching the vase, turns his eyes towards the Christ Emmanuel in the headpiece.

Thus, like all the illustrations in the Gospel of Skewra, this page reflects the feast of the Epiphany and, at the same time, the rite of Lewon's coronation. In its first representation, the Genealogy of Christ acquires liturgical and political connotations and serves as a bearer of royal ideology.

\section{2 The Theme of the Genealogy of Christ during the Reign of Het'um I}

The subject of the genealogy of Christ reappears, only 6o years later, at the end of the reign of King Het'um I (r. 1226-1269). A group of Gospel books produced between 1262 and 1268 features portraits of the ancestors of Christ in connection with Matthew's and Luke's genealogies. ${ }^{21}$ The images are either grouped in a full-page illustration or lined up on the page, respecting the descending and ascending course of these two genealogies (figures. 3.3, 3.4).

Het'um I was a representative of the Het'umid dynasty, a rival of the Rubenids. ${ }^{22}$ He received the crown after his marriage to Zabel, the daughter of Lewon I Rubenid. Because of his young age, his father Kostandin, a prominent Het'umid who had tutored Princess Zabel since 1221, was appointed regent. Until Het'um came of age in 1236, Kostandin was in effect the ruler of the country. Historians thus regard him as a crucial figure in the history of the Armenian Kingdom of Cilicia. ${ }^{23} \mathrm{He}$ stabilized the state through the formation of a clan hierarchy comprising himself and his sons. Through the marriage of his son Het'um to Zabel, he united the Rubenid and Het'umid dynasties, putting an end to their antagonism. But this policy also ensured the continuity of the Het'umid dynasty as well as the hereditary nature of the throne: the blood

20 On this rite, see: Nicholas E. Denysenko, The Blessing of Waters and Epiphany. The Eastern Liturgical Tradition, (Liturgy, Worship and Society Series) (Ashgate, 2012).

21 Mss: Baltimore, Walters Art Museum, W.539 (fols. 15r, 218r); Washington, D.C., Freer Gallery of Art, FGA56.11 (fol. 14v) and FGA32.18 (fols. 2r-4r, 141r); New Julfa (Isfahan), Monastery of the Holy Saviour, NJ57/161 (fols. 15r-17r, 163r-165r, the last ones are empty; the illumination was not completed).

22 Ter-Petrossian, The Crusaders, 2:254-96; Mutafian, L'Arménie du Levant, pp. 337-64.

23 Ter-Petrossian, The Crusaders, 2:273-87. 
of the first Cilician king, Lewon I, would flow through the veins of Kostandin's own posterity.

The reign of Het'um I was marked by extraordinary activity in all spheres of rulership - politics, diplomacy, commerce, and culture - despite the upheavals that shook the Levant in the middle of the 13th century. Though Het'um was an exceptionally skilled ruler and politician, from the point of view of hereditary right and legitimacy of power he always maintained the status of co-governor with his wife. Official documents were signed by both, and on his silver coins Het'um represented himself alongside Zabel, even after the latter's death. ${ }^{24}$ Numerous written sources name Zabel as the legitimate heir. ${ }^{25}$

The reappearance of the Genealogy of Christ in Armenian manuscript painting dates not to the start of Het'um's reign, in 1226, but to 1262, when questions of dynastic continuity and the transmission of power came to be raised at court. The issue became particularly urgent following two important events: the death of the regent Kostandin and the marriage of Het'um and Zabel's son Lewon, the future king Lewon II.

After the death of the regent Kostandin, the powerful role he had played became ever more evident. Upon his death, in recognition of the clan system of rulership that he had established, he was awarded a series of unprecedented honorary titles: 'the Father of the King,' 'the Great Patriarch of the Armenians,' 'the New Patriarch,' and even 'the Abrahamic Elder.'26 It is precisely in this context - exalting the kinship between the king and his father - that the subject matter of the genealogy of Christ reappears in illustrated Gospel books after an interruption of well over 6o years. The patrons of these manuscripts were members of the royal family and/or high dignitaries of the Church, such as Catholicos Kostandin I (1220-1267) and two of the brothers of King Het'um, Bishop John and Prince Vasak. The reappearance of the subject matter in 1262 in connection with an emphasis on royal patrilineal kinship is to be found in the so-called Gospel of Sebastia. ${ }^{27}$ Its colophon refers to Kostandin

\footnotetext{
24 The universalist title 'King of all Armenians' was never applied to Het'um (see above, n. 9).

25 Ter-Petrossian, The Crusaders, 2:268-72.

26 See: Ibid., 2:277-79.

27 Baltimore, Walters Art Museum, W.539. Avedis K. Sanjian, A Catalogue of Medieval Armenian Manuscripts in the United States (Berkeley, 1976), pp. 273-87; Hayeren jeragreri hišatakaranner, XIII dar [Colophons of Armenian Manuscripts, 13th century], ed. Artašes Mat'evosyan (Yerevan, 1984), pp. 314-16; Sirarpie Der Nersessian, Armenian Manuscripts in the Walters Art Gallery (Baltimore, 1973), pp. 10-30, figs. 43-137; Der Nersessian, Miniature Painting, 1:51-76; The Digital Walters: http://www.thedigitalwalters.org/Data/Walters Manuscripts/html/W539/. Accessed 2020 Apr 21.
} 
as 'the Father of the King,' and the Genealogy of Christ is featured as part of the decorative program entrusted to T'oros Roslin, one of the most renowned miniaturists from Armenian Cilicia. To pay homage to Queen Zabel by emphasizing the place of women in sacred genealogy, Roslin even included portraits of the wives mentioned in the Gospel of Matthew: Tamar, Rehab, Ruth, and Bathsheba (Figure. 3.3).

The representation of the genealogy of Christ varies across the larger corpus of manuscripts produced between 1262 and 1268. In one of the Gospel books - ascribed to the end of the 13 th century ${ }^{28}$ - the mention of 'the God of Abraham, Isaac, and Jacob' is visually underlined by portraits of these patriarchs and poses an equivalence between divine election and Abrahamic filiation. In another manuscript - again possibly dating to the end of the 13th century ${ }^{29}$ - among the portraits of the ancestors of Christ, the patriarch Abraham is visually distinguished, occupying a special place (Figure. 3.4). In context, the depiction of Abraham as a patriarch and the forefather of the chosen people spoke directly to the paternal status of the regent Kostandin, who was by then greatly honoured at court.

Another innovation - one with no future in Armenian manuscript illumination, being limited to this specific political-historical context - can be found in these manuscripts. In their canon tables, the prophets are presented with scrolls with messianic messages. ${ }^{30}$ For example, in the Gospel of Sebastia, Isaiah carries a scroll with the verse 'Behold the Virgin will conceive and give birth to a son' (Isa. 7:14), while Zechariah's reads 'Rejoice, daughter of Zion, behold your King and Saviour' (Zech. 9:9) (Figure. 3.5). ${ }^{31}$ Here, the link between the ancestors and the announcement of a supreme king responds to the contemporary controversy in the Armenian Kingdom of Cilicia about dynastic continuity and royal legitimacy.

28 Washington, D.C., Freer Gallery of Art, FGA32.18. Sanjian, A Catalogue of Medieval Armenian Manuscripts, pp. 728-33; Sirarpie Der Nersessian, Armenian Manuscripts in the Freer Gallery of Art (Washington, D.C., 1963), pp. 26-54, figs. 53-181; Der Nersessian, Miniature Painting, 1:55-56.

29 New Julfa (Isfahan), Monastery of the Holy Saviour, NJ57/161. Sirarpie Der Nersessian, and Arpag Mekhitarian, Armenian Miniatures from Isfahan (Brussels, 1986), pp. 36-57; Der Nersessian, Miniature Painting, 1:89-92, 2:figs. 342-43.

30 Der Nersessian, Miniature Painting, 1:64-65, 2:figs. 230-33; Ioanna Rapti, “Gloses prophétiques sur l'Évangile: À propos de quelques manuscrits arméniens enluminés en Cilicie dans les années 126o," Dumbarton Oaks Papers 58 (2004), 119-49, 151-54, esp. 121-29.

31 The full texts on the scrolls of the prophets are reproduced in: Rapti, "Gloses prophétiques sur l'Évangile," pp. 151-53. 
Parallel to the glorification of the regent Kostandin as the founder of the clan system of rulership, Prince Lewon, the son of Het'um and Zabel and the heir to the throne, was also given honorary titles. He was described as porphyrogenitus or 'one born in purple, ${ }^{32}$ a title that first appeared at the Cilician court. His portraits have an air of sacralization. ${ }^{33}$ All this visual and written evidence points to the same ideological function: to exalt both the genealogy of Christ and the forms of kinship current in the Armenian Kingdom of Cilicia by setting the two into dialogue.

The development of this particular concept of sacral kingship owed much to Vardan Arewelc'i ('the Easterner'), an illustrious doctor of the Church, monastic teacher, theologian, historiographer, geographer, philosopher, and translator of the 13th century, who expounded on royal ideology in several of his writings. ${ }^{34}$ In the colophon of his Analysis of the Holy Scriptures (1246), ${ }^{35}$ he positions the king and his family under the direct protection of Christ. ${ }^{36}$ Moreover, he praises the 'porphyrogenetic' princes by means of imagery of flowering, such as 'flourishing,' 'budding,' 'branched. 37

Vardan Arewelc'i applied this same imagery to exalt filiation in his commentary on the Immortal Flower, a Marian hymn within the liturgy of the feast of the Epiphany. ${ }^{38}$ The hymn glorifies holy kinship, which according to the prophet Isaiah (Isa. 11:1-2) sprang from the root of Jesse, the father of King David, as the recipient of seven graces of the Holy Spirit. In his commentary, Vardan develops the notion of Mary as the flower and Christ as the fruit. By drawing a connection between Isaiah's prophecy and biblical genealogy, he magnifies the importance of genealogy. This connection reached its climax

32 Colophons of Armenian Manuscripts, ed. Mat'evosyan, p. 318. This is the colophon of a Gospel book of 1262 (Jerusalem, Armenian Patriarchate, J266o), which also contains the portrait of Lewon with his fiancée Keran, executed by T'oros Roslin.

33 Der Nersessian, Miniature Painting, 2:figs. 640-41.

34 Ant'apyan, P'aylak, Vardan Arevelc'i. Kyanqn u gorcuneut'yuna [Vardan Arevelc'i: Life and Work], 2 vols (Yerevan, 1987-89). Between 1239 and 1248, he had several long stays in Cilicia, at the court of King Het'um I.

Lucmunk' $i$ Surb Groc', collection of texts intended as a study guide for natural sciences, composed for young princes on the request of King Het'um I and better known by the title Žtlank': Ant'apyan, P'aylak, Vardan Arevelc'i, 1:110-26; for the colophon, see: ibid., 1:117-19.

36 Ant'apyan, P'aylak, Vardan Arevelc $i$, 1:118.

37 Ibid., 1:119.

38 The hymn The Immortal Flower is sung on the fifth day of the Epiphany, see: Sharakan (Hymnarium). Matenagirk Hayots / Armenian Classical Authors, 8 (Antelias, 2007), pp. 5152. For the commentary by Vardan Arewelc'i, see: Tamar Tasnapetean, Tiramayr [Mother of God], (Lisbon, 1998), pp. 47-57. 
during the reign of King Lewon II. As we will see below, these concepts resonate in a homily written on the occasion of Lewon II's coronation, and this, in turn, influenced the iconography of Christ's genealogy.

With Vardan, genealogy in general became a means of legitimizing royal power. In 1248, in his Armenian translation of the Chronicle of Michael the Syrian, Vardan includes information on dynastic ties between the Rubenids and the Bagratids, thus linking the Rubenids with the previous Armenian royal dynasty. ${ }^{39}$ Prior to this, the Rubenid kinship ties to the Bagratids were orally circulating legends based on some historical data. According to Levon TerPetrossian, during the reign of Lewon I the link between the two dynasties came to be underscored at a whole new level, reviving the memory of the lost Armenian Kingdom. ${ }^{40}$ Vardan's translation of Michael the Syrian's chronicle remains the oldest written source for the legend..$^{41}$ Vardan employed it with the purpose of buttressing the ideology of the royal dynasty newly established in Cilicia as the successor. ${ }^{42}$ The high point in the development of the legend would be the homily for the coronation of Lewon II, in which the Rubenids now linked to the Bagratids, who claimed a Jewish origin - were proclaimed the offspring of King David himself.

\section{3}

\section{The Theme of the Genealogy of Christ and King Lewon II}

The coronation of Lewon II took place on 6 January 1271. Like his grandfather, he was crowned on the day of the Epiphany. His enthronement was of particular significance because - by uniting the two royal houses, the Rubenids through his mother and the Het'umids through his father - he finally ensured the full flourishing of the kingdom. ${ }^{43}$ His accession marked the emergence of the cult of the 'Ideal Sovereign,' codified in visual and written sources.

39 Tearn Mixayēli patriark'i asorwoc' Žamanakagrut'win [The Chronicle of Michael the Syrian], (Jerusalem, 1870), p. 417. The Bagratids were an ancient noble family that played a significant role in the history of Armenia. The Bagratid Kingdom (885-1045) was the last Armenian state on its historical territory.

$40 \quad$ Ter-Petrossian, The Crusaders, 2:202-04.

41 Ibid., 2:202-04.

42 Such 'legitimizing' tactics were common among royal dynasties that had newly come to power: Ter-Petrossian, The Crusaders, 2:202-o6. Vardan Arewelc'i also notes that, after the restoration of the Armenian Kingdom, the power of the Cilician kings could extend to Armenia itself, see: The Chronicle of Michael the Syrian, p. 511.

Ter-Petrossian, The Crusaders, 2:297-336. 
On the occasion of the coronation of Lewon II, his secretary Vahram of Edessa (or Vahram Rabuni) wrote the Homily on the Epiphany of the Lord and the Coronation of King Lewon. ${ }^{44}$ Therein, he explains the concept of the royal office based on the prophecy of Isaiah concerning the birth of the Messiah from the root of Jesse, the father of King David. In the epigraph, Vahram directly quotes the verses of this prophecy:

There shall come forth a rod out of the stem of Jesse, and a Branch shall grow out of his roots. And the spirit of the Lord shall rest upon him, the spirit of wisdom and understanding, the spirit of counsel and might, the spirit of knowledge and of the fear of the Lord.

Isa. 11:1-2 45

In his homily, Vahram first explains the theological importance of the feast of the Epiphany, before proceeding to define the ideal king and the ideal monarchy. The leitmotif is the anointment, which imbues royal power with divine right in the fullest sense: to be anointed means to be chosen by God, like David and the patriarchs in the Old Testament; the seven gifts of the Holy Spirit are the virtues of an ideal king.

This formulation of 'messianism' on the basis of the prophecy of Isaiah finds its perfect manifestation - both ideologically and artistically - in the Tree of Jesse. With the advent of Lewon II, this subject was introduced into Cilician manuscript art. Although still in later periods of Cilician book art one may find depictions of the Tree of Jesse, the greatest number of such examples date to the reign of Lewon II. ${ }^{46}$ These form part of the larger corpus of royal and princely manuscripts dating to the second half of the 13th century. Among their patrons we find, again, members of the highest elite, i.e. representatives of the royal entourage including Lewon himself, his wife Queen Keran, Lewon's uncles Bishop John and Prince Vasak, and Prince Kostandin - the coronant. ${ }^{47}$

At the court of Lewon II, miniaturists tended to depict the Tree of Jesse as a marginal illumination on the opening page of the Gospel of Matthew, serving

44 Vahram Rabuni, Vahramay vardapeti atenadpri Lewon ark'ayi Ban i Yaytnut'iwn Tearn ew yōcumn Lewoni G. ark'ayi [On the Epiphany of the Lord and on the Coronation of King Lewon, written by Vahram Vardapet, Chancellor of King Lewon], (Jerusalem, 1875). See another edition of this homily in: Ararat, 1/5 (1869).

45 Vahram Rabuni, On the Epiphany, p. 1.

46 Mss: Yerevan, Matenadaran, M9422 (fol. 2or), M2629 (fol. 14r), M7651 (fol. 1or), M979 (fol. 1or); Jerusalem, Armenian Patriarchate, J2568 (fol. 5 r).

Der Nersessian, Miniature Painting, 1:108-10, 2:figs. 428-34. 
to illustrate the genealogy of Christ: Jesse rests under his tree, while David, Solomon, the Virgin, and Christ encapsulate the Incarnation (figures. 3.6, $3.7,3.8$ ). The prophets who announced the coming of the Messiah are no longer represented in the canon tables but find their place along either side of the tree's trunk. The two theological theses articulated through the Tree of Jesse - namely the appearance of the incarnate Messiah and the royal origin of Christ - undergird the royal ideology that Vahram expounds on: with the coronation of Lewon II on the day of the Epiphany, the generation of Armenian kings will begin a new 'growth.'48

In the homily, another technique for legitimizing royal power comes in the affirmation of the prestige of the king's ancestry. At the end of his homily, before finishing his speech, Vahram draws up the genealogy of Lewon II, emphasizing the king's ties to the first Cilician royal house, the Rubenids. ${ }^{49}$ To underscore dynastic continuity, he names Lewon as the son of Zabel (daughter of Lewon I) and forgoes any mention of his Het'umid origins. Moreover, Vahram revives the dynastic legend introduced by Vardan Arewelc'i in the 1240s, whereby the Rubenids were considered the descendants of the Bagratids; he likewise refers to the History of Movsēs Xorenac'i (5th century), which affirmed the Jewish origin of the Bagratids. ${ }^{50}$ In this way, he attributes to the Rubenids an ancestry going back to the biblical king David and designates King Lewon II as a Christomimetic figure. ${ }^{51}$ What subject matter could better illustrate the exceptional status of Lewon II than the Tree of Jesse?

In this group of manuscripts linked to Lewon II, some of the compositions of the Tree of Jesse are surmounted by the Trinity (figures. 3.6, 3.8). This element reappears neither in later Armenian art nor in Byzantine or Western examples. ${ }^{52}$ Some researchers have seen in it an expression of 'monophysite sensitivity, ${ }^{53}$ which would suggest that the inclusion of the Trinity rendered the Tree of Jesse a representation of not only the earthly genealogy of Christ but also his divine nature. Yet, a more convincing interpretation of this innovation

48 Vahram Rabuni, On the Epiphany, p. 20.

49 Ibid., p. 56.

$50 \quad$ Movsēs Xorenac'i (Moses of Khoren), book 1, chapter 22; book 2, chapters 3, 7. See: Moïse de Khorène, Histoire de l'Arménie, ed. Annie Mahé and Jean-Pierre Mahé (Paris, 1993), pp. 140-41, 158, 161. Movsēs Xorenac' i is considered the 'Father of Armenian historiography.'

51 See: Peter S. Cowe, "The Inauguration of the Cilician Coronation Rite and Royal Ideology," Armenian Review 45, 4/18o (1992), 49-59, esp. 53; Ter-Petrossian, The Crusaders, 2:52-53.

52 Der Nersessian, Miniature Painting, 1:110.

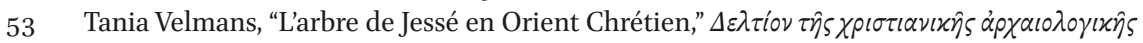

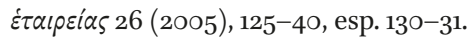


may be found in Vahram's compositions. In his homily on the divine origin of power, he asks rhetorically: "Who is the first king?" In response, he affirms that the first and only real king is God, who is one with the Trinity. ${ }^{54}$ Moreover, the image of the Trinity connects perfectly with the feast of the Epiphany in that the feast itself was thought to be a manifestation of the Trinity and its evocation is linked to the baptism of Christ.

Thus, during the reign of Lewon II, the iconography of the Tree of Jesse and its Christological significance went hand in hand with literary works expressing a theology of power and exalting dynastic continuity. As to the question of the source of inspiration for these representations, which appeared suddenly in Cilician manuscripts in the last quarter of the 13 th century, ${ }^{55}$ we can safely conclude that this motif stood in direct relation to the person of Lewon II, becoming, in a way, a symbol of his royalty. ${ }^{56}$

The reign of Lewon II (1271-1289) marked the peak of the Armenian Kingdom of Cilicia. He deepened and strengthened the state-building process that had begun under Het'um I. In spite of major political upheavals and military clashes, his reign was characterized by stability and unity as well as by active diplomacy with the Mongols and Muslim and European rulers, including the

54 Vahram Rabuni, On the Epiphany, pp. 21-25.

55 Der Nersessian, Miniature Painting, 1:109.

56 Sirarpie Der Nersessian believes that the Tree of Jesse entered Armenian manuscripts through the influence of Western art: Sirarpie Der Nersessian, "Western Iconographic Themes in Armenian Manuscripts," in Sirarpie Der Nersessian, Études byzantines et arméniennes (Louvain, 1973), pp. 611-30. But the problem is more complex; this development in Armenian manuscripts signals the adoption of a concept of political power that was widely exploited by Western rulers from the 11th century onwards. For example, in the Gospel book for the coronation of Vratislaus II of Bohemia (1061-1085), four scenes symbolically announce the coming of the Messiah, including the oldest representation of the motif of the Tree of Jesse (Codex Vyssegradensis, 11th century, Prague, Metropolitan Chapter Library). In 1169, Amaury I of Jerusalem (1163-1174) commissioned a mosaic of the Tree of Jesse in the basilica of the Nativity in Bethlehem, which was the place of the coronation of Latin kings of Jerusalem. In France in the 12th century, representations of the Tree of Jesse had the same political purpose. The Tree of Jesse windows of the basilica of Saint-Denis and the cathedral of Chartres were created with the aim of exalting royal power, see: James R. Johnson, "The Tree of Jesse Window of Chartres: Laudes Regiae," Speculum 36/1 (1961), 1-22. 
papacy. An economic and cultural flourishing accompanied all this. As a result, the kingdom became the hearth of Armenian statehood. ${ }^{57}$

The last manuscript linked to Lewon II that exploits the theme of the genealogy of Christ is the Prince Het'um Lectionary of 1286, which features a royal portrait in the form of a family tree on its opening page..$^{58}$ This manuscript synthesizes the whole ideology behind the theme of genealogy as it evolved over decades at the Cilician court. The genealogy of Christ is visualized twice: through portraits of Christ's ancestors and through the Tree of Jesse, both of which appear in the canon of the Epiphany. The portraits of Christ's ancestors accompany the text of the genealogy of Luke (Lk. 3:23-38). ${ }^{59}$ In contrast to the composition privileged in the $126 \mathrm{os}$, a special place is given to Adam (Figure. 3.9). At the very end of the genealogy that stems from Christ back to God, he is visually distinguished - directly adjacent to the Ancient of Days in the upper-right corner of the page illustrating the verse: "son of Adam, son of God" (Lk. 3:38). Here it is not superfluous to mention that Vahram, too, had paid special attention to Adam in his homily written on the occasion of Lewon's coronation, regarding him as a primordial royal figure, for God created man in his own image and commanded him to rule over all the animals (Ps. $8: 6-9) \cdot{ }^{60}$

The treatment of the Tree of Jesse in this lectionary is particularly striking. It is placed in the margin of the opening page of the canon of the Epiphany (Figure. 3.10), ${ }^{61}$ which opens with the readings prescribed for the celebration of the vigil of the Epiphany on 5 January. Specifically, the image accompanies a reading from the Gospel of John (John 1:1) exalting the Incarnate Word. The composition is enriched by the inclusion of the false prophet Balaam in the lower margin: seated on his donkey, he passes a recumbent lion while en route

57 The reign of Lewon II is the final period of the kingdom's glory. After him, the kingdom gradually fell into decline. Historians thus refer to Lewon as the last great King of Cilicia': Ter-Petrossian, The Crusaders, 2:296.

$5^{8}$ Ms. Yerevan, Matenadaran, M979. This manuscript is a lectionary, i.e. a liturgical book containing the readings for each feast during the liturgical year. On the Armenian lectionary in general and its origins in Jerusalem, see: Athanase (Charles) Renoux, Le codex arménien Jérusalem 121. I. Introduction, aux origines de la liturgie hiérosolymitaine, lumières nouvelles, PO 35/1, n. 163 (1969). The Het'um Lectionary belongs to the second redaction of the Armenian lectionary, which occurred between 1173 and 1198 in Cilicia. Renoux, Le Lectionnaire de Jérusalem, pp. 46o-61, 474-77, 509; Charles Renoux, "Le Čašoc' arménien au creuset cilicien," Hask - Armenological Review 11 (2007/o8), 385-96.

59 Ms. Yerevan, Matenadaran, M979, fols. 44v-45r. The genealogy of Luke is part of the readings for the eighth day of the Epiphany.

6o Vahram Rabuni, On the Epiphany, p. 25.

61 Ms. Yerevan, Matenadaran, M979, fol. 1or. 
to the Tree of Jesse. An exceptional case in the Cilician corpus of Tree of Jesse images, this evokes the messianic prophecy of Balaam (Num. 24:9). ${ }^{62}$

The representation of the Tree of Jesse is distinguished from all known Cilician examples and sets forth a series of interesting features. In this image loaded with bust figures, Christ is located in the middle of the composition loaded with bust figures. Between him and Jesse, we find David, Solomon, and the Virgin, following the ascending genealogy of Matthew. Above Christ, there are old men - probably patriarchs, who, according to the sequence of the genealogy of Luke, align with the Ancient of Days, which is preceded by Adam. In Cilician manuscripts generally, this is the only case in which the genealogical sequences of Matthew and Luke are combined within the same composition, thus constituting a symbolic image of the genealogy of Christ and not an illustration of any precise text.

This becomes even more significant in light of Vahram's writings. At the end of his homily, he offers two formulations of the genealogy of Lewon II, imitating the arrangement of Matthew's and Luke's respective genealogies of Christ:

King Lewon is the tenth Rubenid according to power and the seventh according to the generations that can be listed as follows: Prince Ruben, Prince Kostandin, Great Prince T'oros said Protosebastos, Prince Lewon, Prince T'oros, Prince Mleh, Prince Ruben, King Lewon, Queen Zabel; and by birth he is the son of Zabel, the daughter of King Lewon, the son of Step'anē, the son of Lewon, the son of Kostandin, the son of Ruben, of the generation of King Gagik of the Bagratid family, of the race of the great David, king and prophet. ${ }^{63}$

In the lectionary, the selection of patriarchs in the composition of the Tree of Jesse also raises questions. The three figures above Christ must be Abraham, Isaac, and Jacob, figures indispensable to the genealogy of Christ and symbolizing divine election. The figure preceding the Ancient of Days is Adam, who,

62 The symbolism of Num. 24:9 is based on Jacob's blessing on his sons, which foretells Judah's priority among all the tribes (Gen. 49:8-12). The blessing was taken as a messianic announcement, and the image of the lion was retained as a symbol of Judah (Rev. 5:5). Balaam's blessing on the house of Jacob exactly repeats the formula of latter's blessing on Judah. Another of Balaam's prophecies, on the star of Jacob (Num. 24:17), was interpreted as a harbinger of the nativity of Christ (Matt. 2:2). Vahram of Edessa likewise discusses the connection between the prophecies of Num. 24:9 and of Isa. 11:1-2 in his homily for Lewon II's coronation. However, given the limited space of this article, this issue will not be discussed here but rather in another forthcoming study.

Vahram Rabuni, On the Epiphany, p. 56. 
as noted above, is highlighted in the previous image (Figure. 3.9). ${ }^{64}$ As for the identification of the four old men placed between Abraham and Adam (the genealogy of Luke lists 19 names between them), one can once again look to Vahram's homily. In the chapter titled "How and by whom royalty came into the world," which speaks of the time when mankind did not yet have royal power but was governed by the patriarchs, he cites Abraham and those who came before him: Noah, Enoch, Enos, and Seth. ${ }^{65}$

The homily for the coronation of the king was not Vahram's only ideologically charged work. On the order of Lewon II, he also devoted a long poem to the history of the kingdom. ${ }^{66}$ This rhymed chronicle exalts the Rubenid dynasty from its origins - without failing to recall the dynasty's Bagratid ancestry ${ }^{67}$ - up to Lewon II, ending around $1275 .{ }^{68}$ Like the homily, it centres on notions of dynastic continuity and legitimacy.

Vahram's chronicle was a source of inspiration for Prince Het'um, a son of Lewon II and the patron of our lectionary, when he wrote the colophon of the manuscript. In this long colophon, Het'um describes the history of the Armenian Kingdom of Cilicia from its foundation up to the reign of his father. ${ }^{69}$ He notes that he himself commissioned this manuscript to glorify the Rubenid dynasty and, like Vahram, avoids mentioning the Het'umids, even accounting for the legality of the actions of the regent Kostandin - a prominent member of the latter family - with recourse to his familial ties to Lewon $\mathrm{I}^{70}$ In addressing praise to his ancestors, he repeats formulas from Vahram.

It was this Cilician approach to the concept of genealogy that inspired the iconography of the royal family tree. Therefore, it is not surprising that we find an image of precisely this type in the Prince Het'um Lectionary - the image

64 The description of the miniature is wrong in: Der Nersessian, Miniature Painting, 1:109.

65 Vahram Rabuni, On the Epiphany, p. 26.

66 Vahramay Rabunwoy Patmut'iwn Rंubeneanc' [Vahram Rabuni's History of the Rubenids], ed. Karapet Šahnazareanc' (Paris, 1859). French translation: "Chronique en vers des rois de la Petite Arménie par le docteur Vahram d'Édesse," in Recueil des historiens des Croisades: Documents arméniens 1, trans. Édouard Dulaurier (Paris, 1869), pp. 493-535. English translation: Charles F. Neumann, Vahram's Chronicle of the Armenian Kingdom in Cilicia during the Time of the Crusades (London, 1831).

67 Vahram Rabuni's History of the Rubenids, ed. Šahnazareanc', p. 192.

68 This is the probable date of creation of this chronicle.

69 Colophons of Armenian Manuscripts, ed. Mat'evosyan, pp. 582-89.

70 Regent Kostandin's kinship with the Rubenids is mentioned in some contemporary colophons, but this does not correspond to any historical reality: Ter-Petrossian, The Crusaders, 2:284-86; Colophons of Armenian Manuscripts, ed. Mat'evosyan, pp. 486, 641. For Het'um's colophon, see: ibid., p. 587. 
with which this essay began (Figure. 3.1). ${ }^{71}$ It appears on the opening page of the lectionary, accompanying the solemnities of 1 January. ${ }^{72}$ The liturgical readings begin with a passage from the Book of Proverbs (Prov. 11:2-11), whose author, Solomon, is depicted in the large, decorative header of the page, symbolically evoking the virtues of an ideal king.

In the margin, the royal portrait is housed within a tree structure: six figures are aligned vertically in a descending progression (Figure. 3.11). ${ }^{73}$ At the top, two kings - one an elderly man, with grey hair and a grey beard, and the other of mature age - are seated in majesty in identical postures (Figure. 3.12a). Each is crowned and haloed and holds the orb in his left hand, while his right hand rests on his hip. Beneath them are four younger figures holding liturgical objects.

To date, the two kings have been identified as Lewon II and his heir Het'um, the patron of this manuscript. However, given the ideological charge and political scope of this image-type in the context of the Armenian Kingdom of Cilicia, it is difficult at present to accept this identification. The posture of a king seated in majesty, like what we find in our miniature, is specific to sacred kings. In addition, our image predates the enthronement of Het'um, which would take place three years later, in $1289 .{ }^{74}$ Could Prince Het'um, already in 1286 , have commissioned his portrait according to the iconography of a sacred king clad in regalia? Would he have dared to represent himself in this way, whereas in his colophon he refers to himself as 'Baron Het'um' and to his father as the 'Reigning King' or the 'Holy King Crowned by Christ'? To begin answering these questions, I propose a new identification of these two portraits: Lewon II below and Lewon I above. In his homily for Lewon II's coronation, Vahram attached particular importance to his right to rule as heir to the throne, viewing the legitimacy of his power - "a generic and patriotically righteous heritage from ancestors" - as one of the three main factors guaranteeing the stability of the state, along with piety and wise leadership. ${ }^{75}$ Vahram validated his enthronement by linking this concept of ancestrally rooted legitimacy to Lewon II's anointing, emphasizing his Ṙubenid line of royal ancestry and particularly the

71 Ms. Yerevan, Matenadaran, M979, fol. $7 \mathrm{r}$.

72 See the modification made to the Armenian lectionary in the Cilician period (above, n. 58). The 1st of January is the day of commemoration for Basil of Caesarea, whose portrait appears on the opposite page.

73 For common images of dynastic trees, see: Christiane Klapisch-Zuber, L'arbre des familles (Paris, 2003).

74 In fact, Het'um was never crowned, see: Ter-Petrossian, The Crusaders, 2:336-79.

75 Vahram Rabuni, On the Epiphany, pp. 53-54. 
fact that he was the son of Queen Zabel and thus the full heir to Lewon ${ }^{7}{ }^{76}$ The primary task of royal ideology was to demonstrate Lewon II's hereditary right. The peculiar status of Lewon II's right to the throne is also emphasized in other contemporary written sources, including colophons. Lewon's royalty is perceived as "a new restoration and a new joy of the Rubenid Dynasty," and he is referred to as "the son of Queen Zabel, the daughter of King Lewon" or "the purple-born king worthy of the crown of King Lewon the Second, the grandson of the First Great Rubenid."77

The importance of his filiation is also made evident in the chronicle of Vahram of Edessa. Here, Lewon II always appears as a Rubenid and as the continuator of the royal dynasty. The parallels between the two Lewons reach a culminating point when Vahram narrates the details of their coronations in nearly identical terms. ${ }^{78}$ Below are the relevant extracts from the chronicle, taken from the English translation by Charles F. Neumann: ${ }^{79}$

\section{About Lewon I}

The Armenians assembled together in the city of Tarsus, and in the cathedral of that town the Catholicos anointed Leon, as it is the custom, king of the house of Thorgoma, to sit on the throne and flourish in kindness; to glorify the Church, and to govern well the country to collect together the dispersed people, and to renovate its power; lastly, to fill the country with peace and to make it as happy as Paradise.

\section{About Lewon II}

... he called a great assembly of Armenians to Tarsus with the patriarch to anoint him, and to fulfill the duties of the Church. Leon received the scepter with the golden globe in his right hand, and the Holy Ghost descended on him, - to be king on the house of Thorgoma; to govern and to defend the flock after the law of God. Leon, sitting on the throne of his forefathers, was gracious to everybody ...

Prince Het'um employs exactly the same formulas in the colophon of his lectionary. In the context of the coronation of Lewon I, he says: "The throne and the sceptre of the royalty of Togarmah were renewed, the country was

$76 \quad$ Ibid, p. 56 .

77 For more details on this, see: Ter-Petrossian, The Crusaders, 2:318-21.

78 Vahram Rabuni, History of the Rubenids, pp. 215, 228.

79 Neumann, Vahram's Chronicle of the Armenian Kingdom in Cilicia, pp. 44, 54. 
filled with peace and kindness, like a flourishing Paradise." 80 The expression 'king of the house of Togarmah,' which appears in these sources as well as in the Cilician ordo for the coronation of the king, ${ }^{81}$ accentuates the antiquity of Armenian royalty, restored in Cilicia but going back to the origin of the nation and its primordial ancestors Hayk and Togarmah. ${ }^{82}$ The shared location and date for their coronations - at the cathedral of Tarsus on 6 January, the feast of the Epiphany - are deemed further evidence of the parallel between Lewon I and Lewon II.

This consistent juxtaposition of the two Lewons seems also to have inspired the illumination at the opening to the lectionary: the two kings are represented in the same posture of sacred majesty, close to the iconography of official images of Lewon I (Figure. 3.12b). Let us recall that Lewon II adopted the universalist title 'King of all Armenians,' which had been previously been employed only by Lewon I. ${ }^{83}$ Thus, in the Het'um Lectionary the image of the dynastic tree of the royal family is dominated by Lewon II's illustrious ancestor. ${ }^{84}$ This image is placed on the opening page of a manuscript that aimed to glorify the royal family of the Rubenids, as attested in the colophon of its patron.

The four other figures in our image are traditionally identified as the sons of Lewon II. ${ }^{85}$ This hypothesis is quite plausible. The composition, as well as the insertion of the figures into a vegetal setting more generally, underscores filiation and hierarchy. But what particularly deserves attention are the objects that the figures hold. The figure immediately beneath Lewon II holds a golden crown; the third figure from the bottom holds a chalice; the figure beneath him holds an ewer for the Holy Chrism; and the figure at the bottom holds a sceptre. Together, these were the sacred objects employed during the coronation ceremony and therefore emblematic of this rite. ${ }^{86}$ However, it seems to me that beyond allusions to the coronation ceremony, these objects carry a deeper

8o Colophons of Armenian Manuscripts, ed. Mat'evosyan, p. $5^{86 .}$

81 See: Davt'yan, The Ordo of Coronation in the Armenian Church, p. 79: "The throne of the royalty of the house of Togarmah and the race of Hayk."

82 Togarmah, a biblical figure, grandson of Gomer, descendant of Japheth and Noah. According to Movsēs Xorenac'i's genealogy of Greater Armenia, Togarmah is the father of Hayk, patriarch of the Armenians, in: Movsēs Xorenac'i (Moses of Khoren), book 1, chapters 5, 9, 10, 12. See: Moïse de Khorène, Histoire de l'Arménie, pp. 110-113, 117-119, 120, 123-126.

83 See above, n. 9, and 24.

84 This scheme is well known in the iconography of family trees, see: Klapisch-Zuber, L'arbre des familles.

85 Drampian, Lectionary of King Hetum II, pp. 98-99.

86 See: Davt'yan, The Ordo of Coronation in the Armenian Church, pp. 74-9o. 
symbolic value pertaining to the king's functions in light of the theology of power. Unfortunately, I cannot treat this compelling topic here but intend to do so in another context. One thing is certain: all the elements of this image serve to convey the core idea that royal power is founded upon hereditary monarchy and dynastic continuity.

\section{5 Conclusion}

In the Armenian Kingdom of Cilicia, the genealogy of Christ was used strategically to legitimate royal power. More generally, parallel with the establishment and solidification of the kingdom, genealogies became an important aspect of the ideology of the ruling elite. This genealogical preoccupation found expression both in written and visual sources, for example in the depiction of Christ's genealogy in Cilician manuscript illuminations. In addition to being an element of Christian iconography, this iconography reflected the concerns associated with royal power: political theology adapted sacred history to its needs, rendering it an instrument of political propaganda. The representation of the genealogy of Christ became an image exalting royal power.

This occurred at the Cilician court at a time when questions of dynastic continuity and the transmission of power were critical. In this context, the introduction of the Tree of Jesse may have been linked to the promotion of the cult of the 'Ideal Sovereign' by the Cilician ruling elite, thus acting in service of the ideology of rulership. This underpinning of royal ideology with genealogy gave rise to the iconography of the portrait of the royal family in the form of a family tree, like that in the Het'um Lectionary. This study, moreover, highlights the relationship between texts and images in the Cilician context: literary works expressing ideology found their counterpart in illuminated miniatures. The image was both a reflection of the textual elaborations on this topic and a statement on its own right.

\section{Acknowledgements}

This article benefitted from a European Institutes for Advanced Study (EURIAS) fellowship at the Paris Institute for Advanced Studies, co-funded by Marie Skłodowska-Curie Actions, under the European Union's 7th Framework Programme for research, and from a funding from the French State programme 'Investissements d'avenir,' managed by the French National Research Agency (ANR-11-LABX-0027-01 Labex RFIEA+). 


\section{Bibliography}

\section{Primary Sources}

Ant'apyan, P'aylak, Vardan Arevelc'i. Kyanqn u gorcuneut'yunə [Vardan Arevelc'i: Life and Work], 2 vols (Yerevan, 1987-89).

"Chronique en vers des rois de la Petite Arménie Recueil des historiens des Croisades: Documents arméniens 1, trans. Édouard Dulaurier (Paris, 1869), pp. 493-535.

Moïse de Khorène, Histoire de l'Arménie, ed. Annie Mahé and Jean-Pierre Mahé (Paris, 1993).

Neumann, Charles F., Vahram's Chronicle of the Armenian Kingdom in Cilicia during the Time of the Crusades (London, 1831).

Sharakan (Hymnarium). Matenagirk Hayots / Armenian Classical Authors, 8 (Antelias, 2007).

Tearn Mixayēli patriark'i asorwoc'Žamanakagrut'win [The Chronicle of Michael the Syrian], (Jerusalem, 1870).

Vahramay Rabunwoy Patmut'iwn Rubeneanc' [Vahram Rabuni's History of the Ṙubenids], ed. Karapet Šahnazareanc' (Paris, 1859).

Vahram Rabuni, Vahramay vardapeti atenadpri Lewon ark'ayi Ban i Yaytnut'iwn Tearn ew yōcumn Lewoni G. ark'ayi [On the Epiphany of the Lord and on the Coronation of King Lewon, written by Vahram Vardapet, Chancellor of King Lewon], Ararat, 1 / 5 (1869).

Vahram Rabuni, Vahramay vardapeti atenadpri Lewon ark'ayi Ban i Yaytnut'iwn Tearn ewyōcumn Lewoni G. ark'ayi [On the Epiphany of the Lord and on the Coronation of King Lewon, written by Vahram Vardapet, Chancellor of King Lewon], (Jerusalem, $1875)$.

\section{Secondary Sources}

Chookaszian, Levon, "The Five Portraits of King Levon II (1270-89) of Armenian Kingdom of Cilicia and their Connections to the Art of Mediterranean Area," in Medioevo: immagini e ideologie, Atti del Convegno internazoinale di studi, Parma, 2327 settembre 2002, ed. Arturo Carlo Quintavalle (Milano, 2005), pp. 129-37.

Cowe, Peter S., "The Inauguration of the Cilician Coronation Rite and Royal Ideology," Armenian Review 45, 4/180 (1992), 49-59.

Das Lemberger Evangeliar: eine wiederentdeckte armenische Bilderhandschrift des 12. Jahrhunderts, eds. Günter Prinzing, and Andrea Schmidt (Wiesbaden, 1997).

Davt'yan, Derenik, Tagavorōrhnek'i kanonə hay eketec'um [The Ordo of Coronation in the Armenian Church], Ph.D. for Vardapet ecclesiastical title (Holy See of Ēǰmiacin, 200o).

Delpech, Marc, and Voisin, Jean-Claude, "La mission en Cilicie de Wilbrand von Oldenburg en 1211-1212. Journal de route de Wilbrand," Mélanges de l'Université Saint-Joseph 56 (1999-2003), 291-346. 
Denysenko, Nicholas E., The Blessing of Waters and Epiphany. The Eastern Liturgical Tradition, (Liturgy, Worship and Society Series) (Ashgate, 2012).

Der Nersessian, Sirarpie, Armenian Manuscripts in the Freer Gallery of Art (Washington, D.C., 1963).

Der Nersessian, Sirarpie, Armenian Manuscripts in the Walters Art Gallery (Baltimore, 1973).

Der Nersessian, Sirarpie, "Western Iconographic Themes in Armenian Manuscripts," in Sirarpie Der Nersessian, Études byzantines et arméniennes (Louvain, 1973), pp. $611-30$.

Der Nersessian, Sirarpie, and Mekhitarian, Arpag, Armenian Miniatures from Isfahan (Brussels, 1986).

Der Nersessian, Sirarpie, Miniature Painting in the Armenian Kingdom of Cilicia from the Twelfth to the Fourteenth Century, 2 vols (Dumbarton Oaks Studies, 31) (Washington, D.C., 1993).

Drampian, Irina, Lectionary of King Hetum II. Armenian illustrated codex of 1286 A.D. (Yerevan, 2004).

Grigoryan, Gohar, Royal Images of the Armenian Kingdom of Cilicia (1198-1375) in the Context of Mediterranean Intercultural Exchange, Ph.D. (University of Fribourg, Switzerland, 2017).

Hayeren jeragreri hišatakaranner, XIII dar [Colophons of Armenian Manuscripts, $13^{\text {th }}$ century], ed. Artašes Mat'evosyan (Yerevan, 1984).

Johnson, James R., “The Tree of Jesse Window of Chartres: Laudes Regiae," Speculum 36/1 (1961), 1-22.

Klapisch-Zuber, Christiane, L'arbre des familles (Paris, 2003).

Levon I. Ein Armenischer König im Staufischen Outremer, eds. Christian Philipsen, Thomas Bauer-Friedrich, and Ulf Dräger (Halle, 2019).

Mutafian, Claude, L'Arménie du Levant, XI ${ }^{e}-X I V^{e}$ siècles, 2 vols (Paris, 2012).

Prinzing, Günter, "Zur Bedeutung und Geschichte des Lemberger Evangeliars," in Das Lemberger Evangeliar: eine wiederentdeckte armenische Bilderhandschrift des 12. Jahrhunderts, eds. Prinzing, and Schmidt (Wiesbaden, 1997), pp. 11-26.

Prinzing, Günter, and Evans, Helen C., "The L'viv Gospels," in The Glory of Byzantium: Art and Culture of the Middle Byzantine Era, A.D. 843-1261, eds. Helen C. Evans, and William D. Wixom (New York, 1997), pp. 361-62.

Rapti, Ioanna, "Gloses prophétiques sur l'Évangile: À propos de quelques manuscrits arméniens enluminés en Cilicie dans les années 126o," Dumbarton Oaks Papers $5^{8}$ (2004), 119-49, 151-54.

Rapti, Ioanna, "Image et liturgie à la cour de Cilicie: Le lectionnaire du prince Het'um (Matenadaran MS 979)," Monuments et Mémoires de la Fondation Eugène Piot 87 (2008), 105-42. 
Renoux, Athanase (Charles), Le codex arménien Jérusalem 121. I. Introduction, aux origines de la liturgie hiérosolymitaine, lumières nouvelles, PO 35/1, n. 163 (1969).

Renoux, Charles, "Le Čašoc' arménien au creuset cilicien," Hask-Armenological Review 11 (2007/08), 385-96.

Renoux, Charles, Le Lectionnaire de Jérusalem en Arménie: Le Čašoc' 1. Introduction et liste des manuscrits, $\mathrm{PO} 44 / 4$, n. 200 (1989).

Sanjian, Avedis K., A Catalogue of Medieval Armenian Manuscripts in the United States (Berkeley, 1976).

Schmidt, Andrea, "L'Évangile de Lemberg: un itinéraire rocambolesque," in Arménie. La magie de l'écrit, ed. Claude Mutafian (Paris, 2007), pp. 26o-63.

Tasnapetean, Tamar, Tiramayr [Mother of God], (Lisbon, 1998).

Ter-Petrossian, Levon, Xačakirnerə ev Hayerə [The Crusaders and the Armenians], 2 vols (Yerevan, 2005/o7).

T'orosyan, Vahe, "Kilikiayi Hayoc' t'agavor Lewon Mecagorci t'agadrman xndri šurj’” [On the Crowning of Lewon the Great, Armenian King of Cilicia], Ejmiacin 12 (2016), 84-112.

Vardanyan, Edda, "Un Maštoc' d'ordination et de sacre royal du XVe siècle," Revue des Études Arméniennes 29 (2003-04), 167-233.

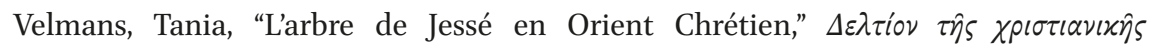

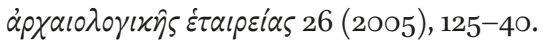

von Euw, Anton, "Das Lemberger Evangeliar als Kunstwerk," in Das Lemberger Evangeliar: eine wiederentdeckte armenische Bilderhandschrift des 12. Jahrhunderts, eds. Prinzing, and Schmidt (Wiesbaden, 1997), pp. 39-92. 


\section{Illustrations}

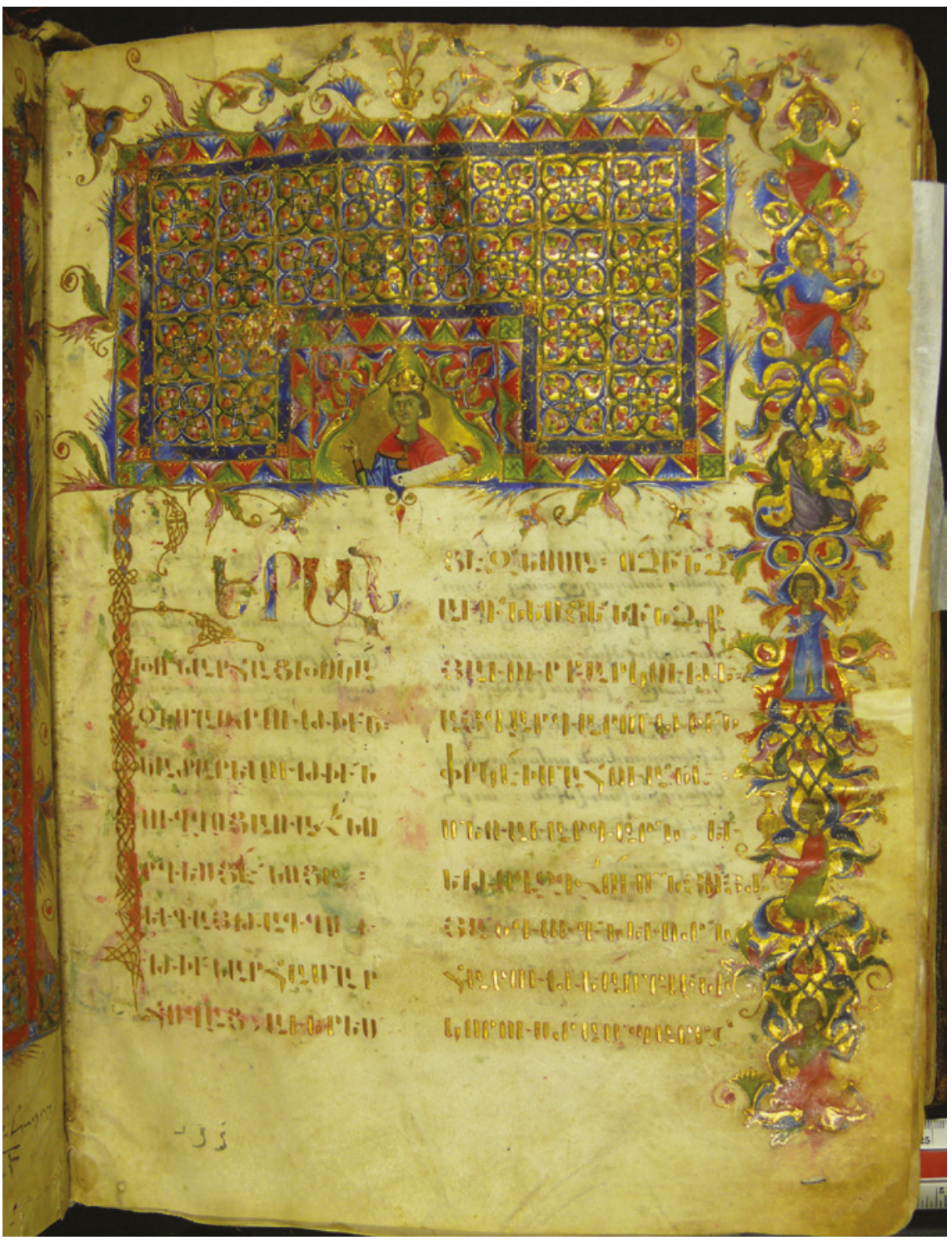

FIGURE 3.1 Title page. Het'um's Lectionary (1286), Yerevan, Matenadaran 979, fol. 7r WITH KIND PERMISSION OF MATENADARAN 


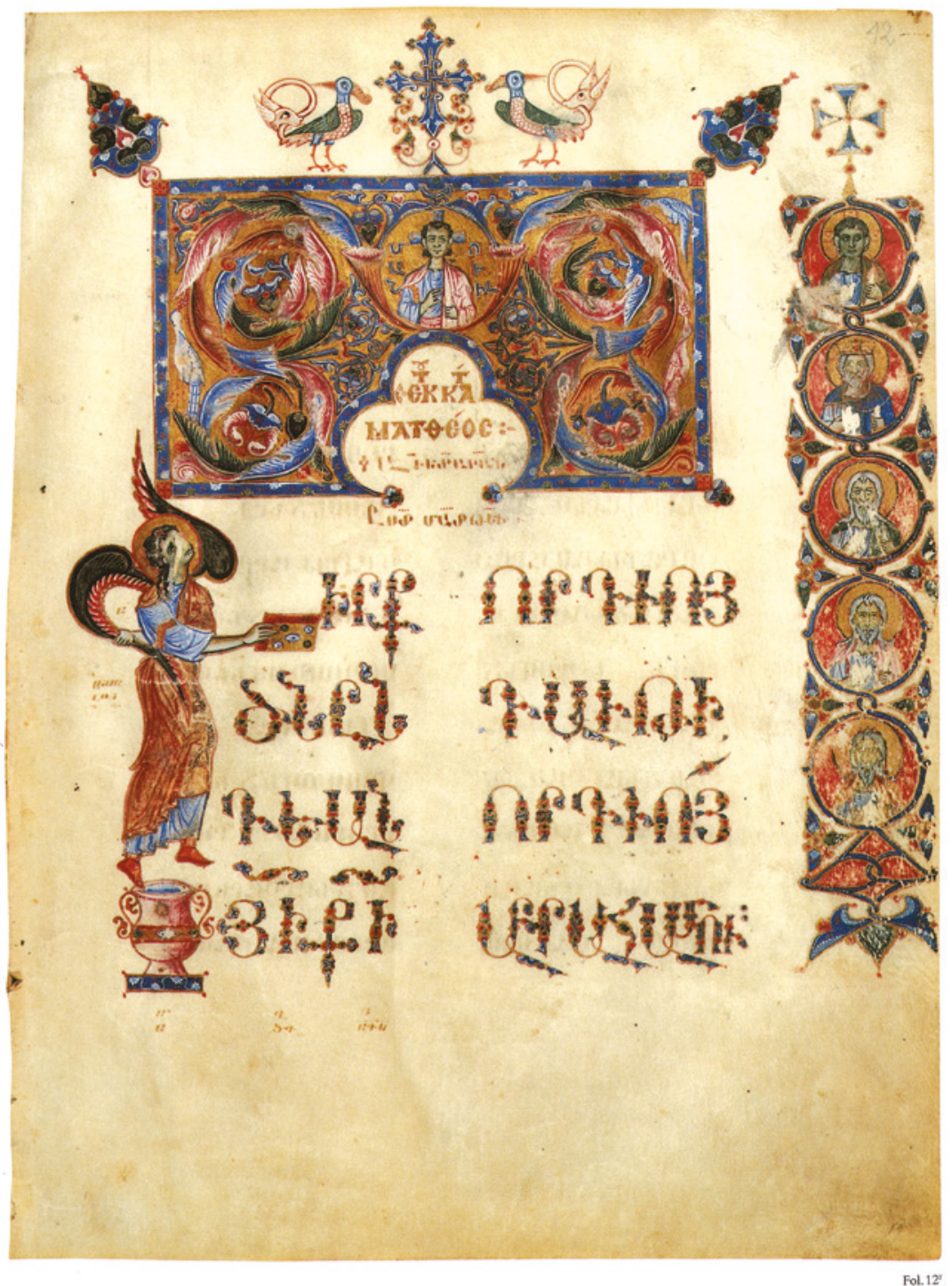

Tafel XI

FIGURE 3.2 Title page of the Gospel of Matthew. The Skewra Gospel (1198), Varsovie, Biblioteka Narodowa, Akc. 1768o, fol. 12r

FROM: DAS LEMBERGER EVANGELIAR, TAF. XI 


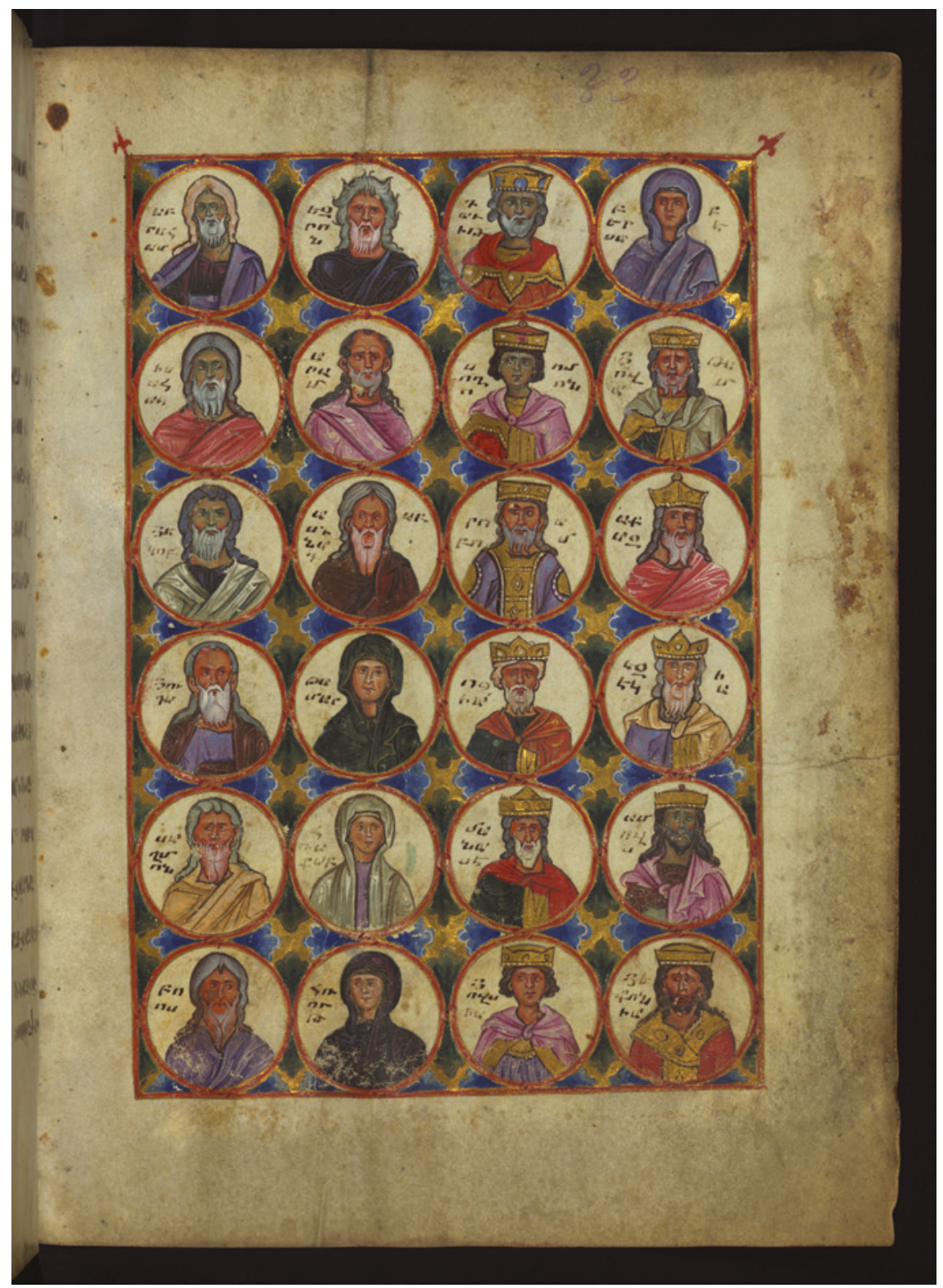

FIGURE 3.3 Ancestors of Christ. Gospel of Sebastia (1262), Baltimore, Walters Art Museum, W.539, fol. $15 \mathrm{r}$

(C) THE DIGITAL WALTERS: HTTP://WWW.THEDIGITALWALTERS.ORG/DATA/ WALTERSMANUSCRIPTS/HTML/W539/ 


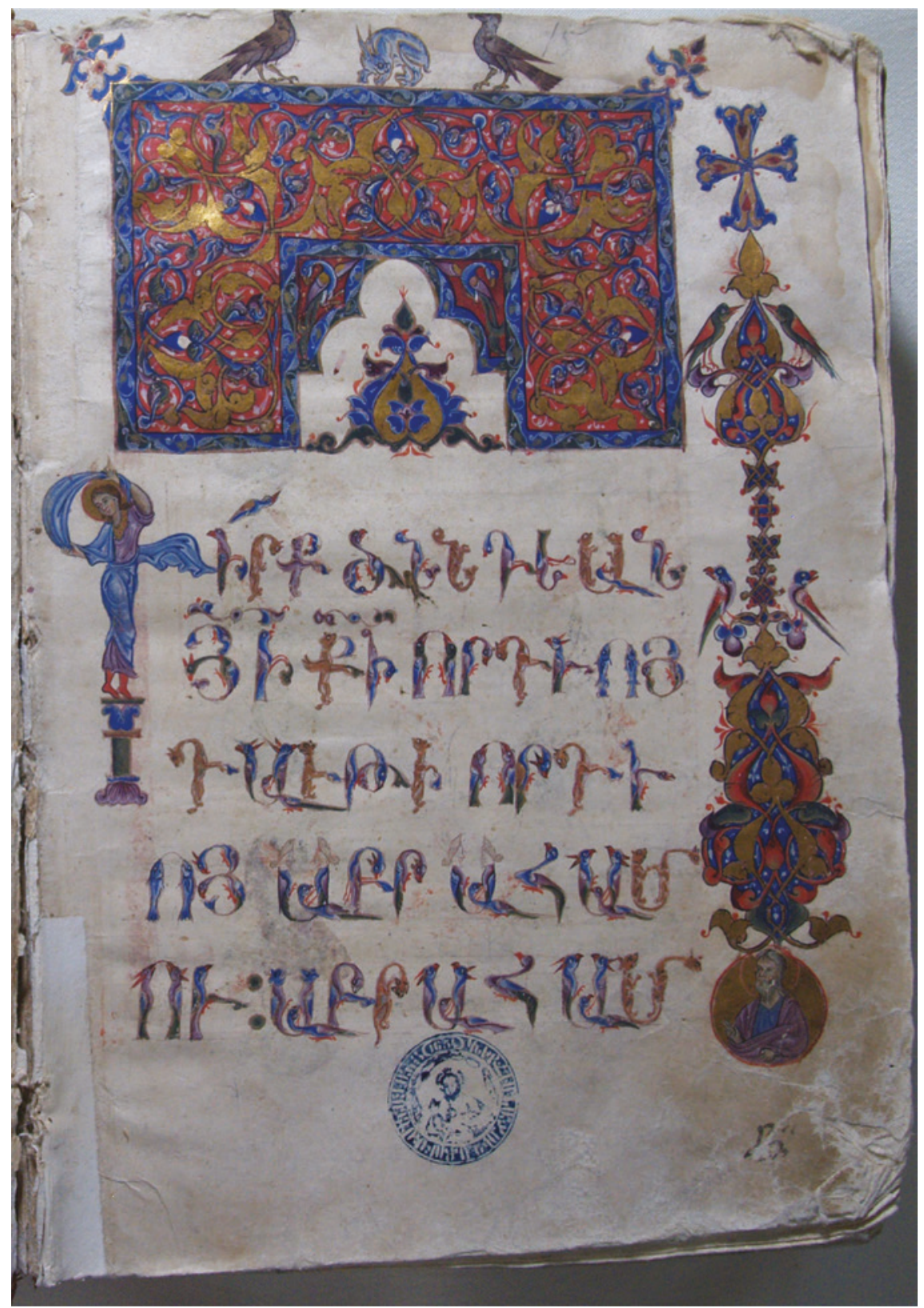

FIGURE 3.4 Ancestors of Christ. Gospel, 13th century, New Julfa (Isfahan), Monastery of the Holy Savior $57 / 161$, fol. $15 \mathrm{r}$ 


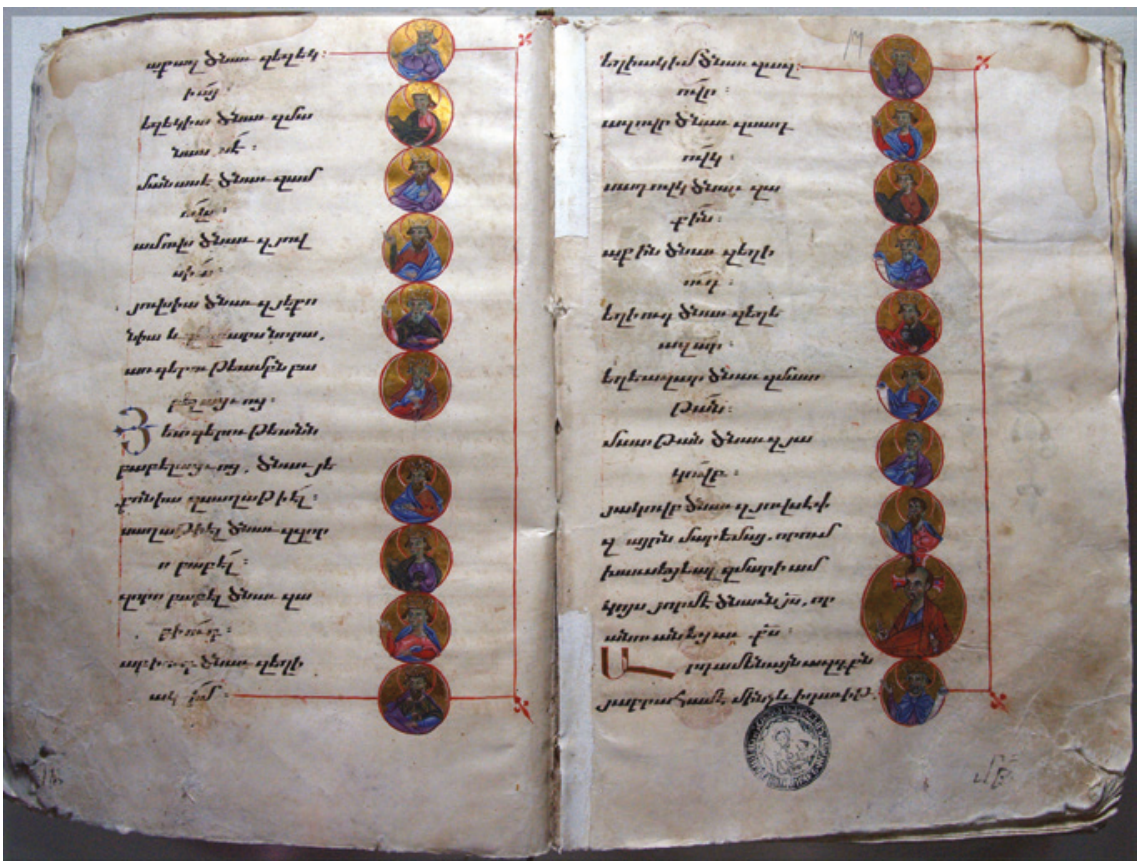

FIGURE 3.4 Ancestors of Christ. Gospel, 13th century, New Julfa (Isfahan), Monastery of the Holy Savior $57 / 161$, fols. $16 \mathrm{v}-17 \mathrm{r}$ WITH KIND PERMISSION OF THE MONASTERY OF THE HOLY SAVIOR 


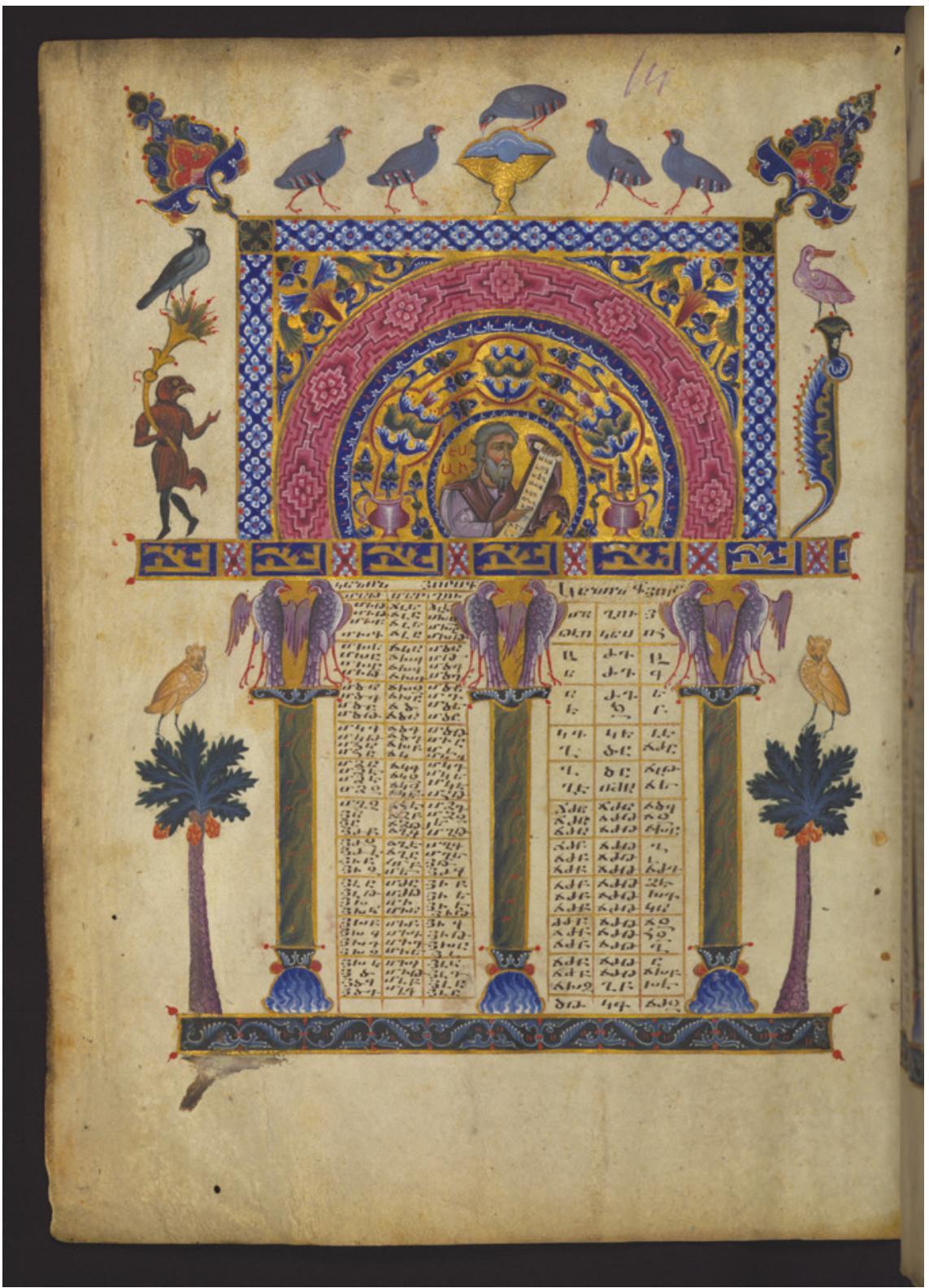

FIGURE 3.5 The prophets Isaiah and Zechariah in the Canon Tables. Gospel of Sebastia (1262), Baltimore, Walters Art Museum, W.539, fol. $5 \mathrm{~V}$ 


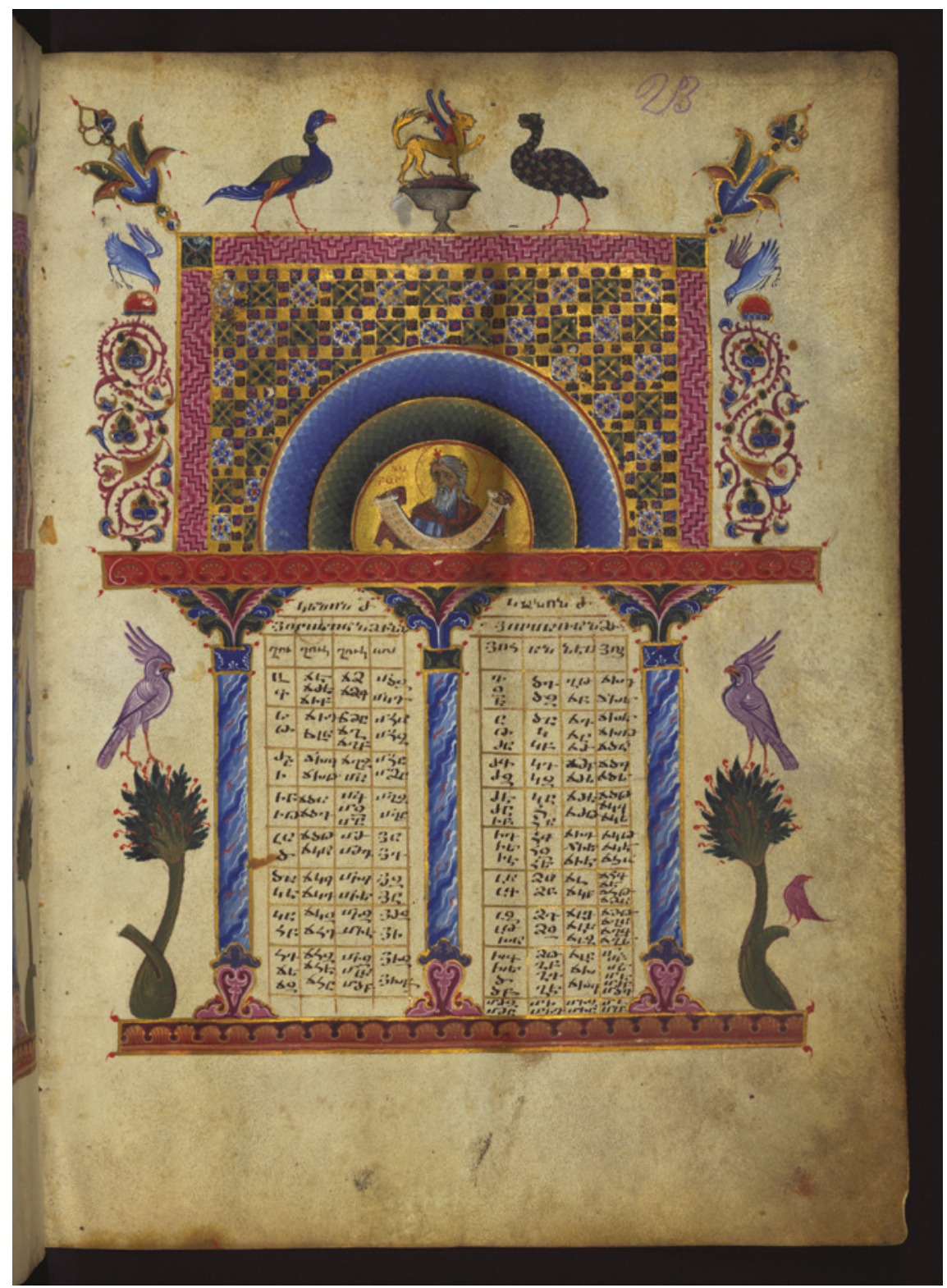

FIGURE 3.5 The prophets Isaiah and Zechariah in the Canon Tables. Gospel of Sebastia (1262), Baltimore, Walters Art Museum, W.539, fol. 1or

(C) THE DIGITAL WALTERS: HTTP://WWW.THEDIGITALWALTERS.ORG/DATA/ WALTERSMANUSCRIPTS/HTML/W539/ 


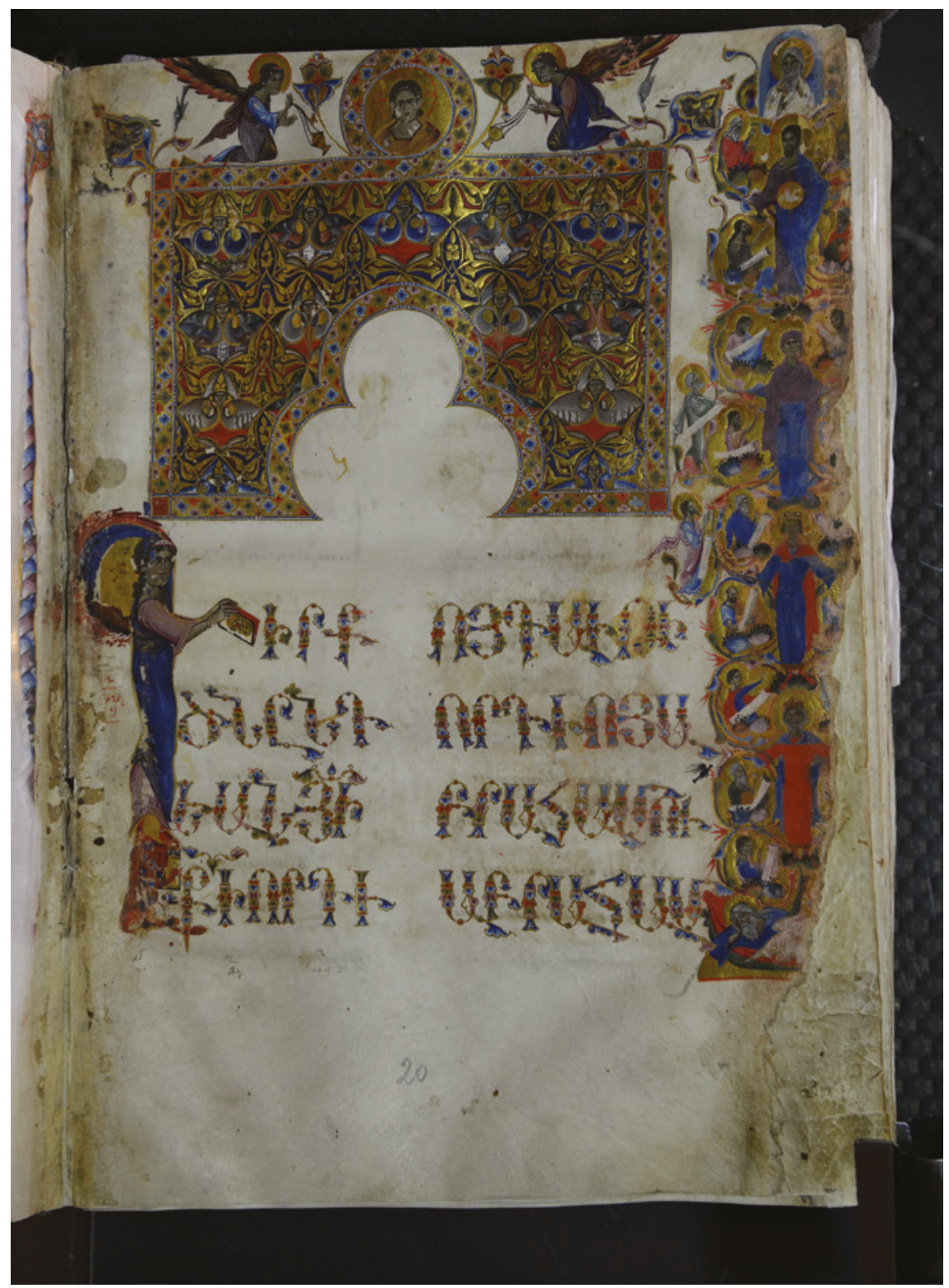

FIGURE 3.6 Tree of Jesse. Gospel, 13th century, Yerevan, Matenadaran 9422, fol. 2 or WITH KIND PERMISSION OF MATENADARAN 


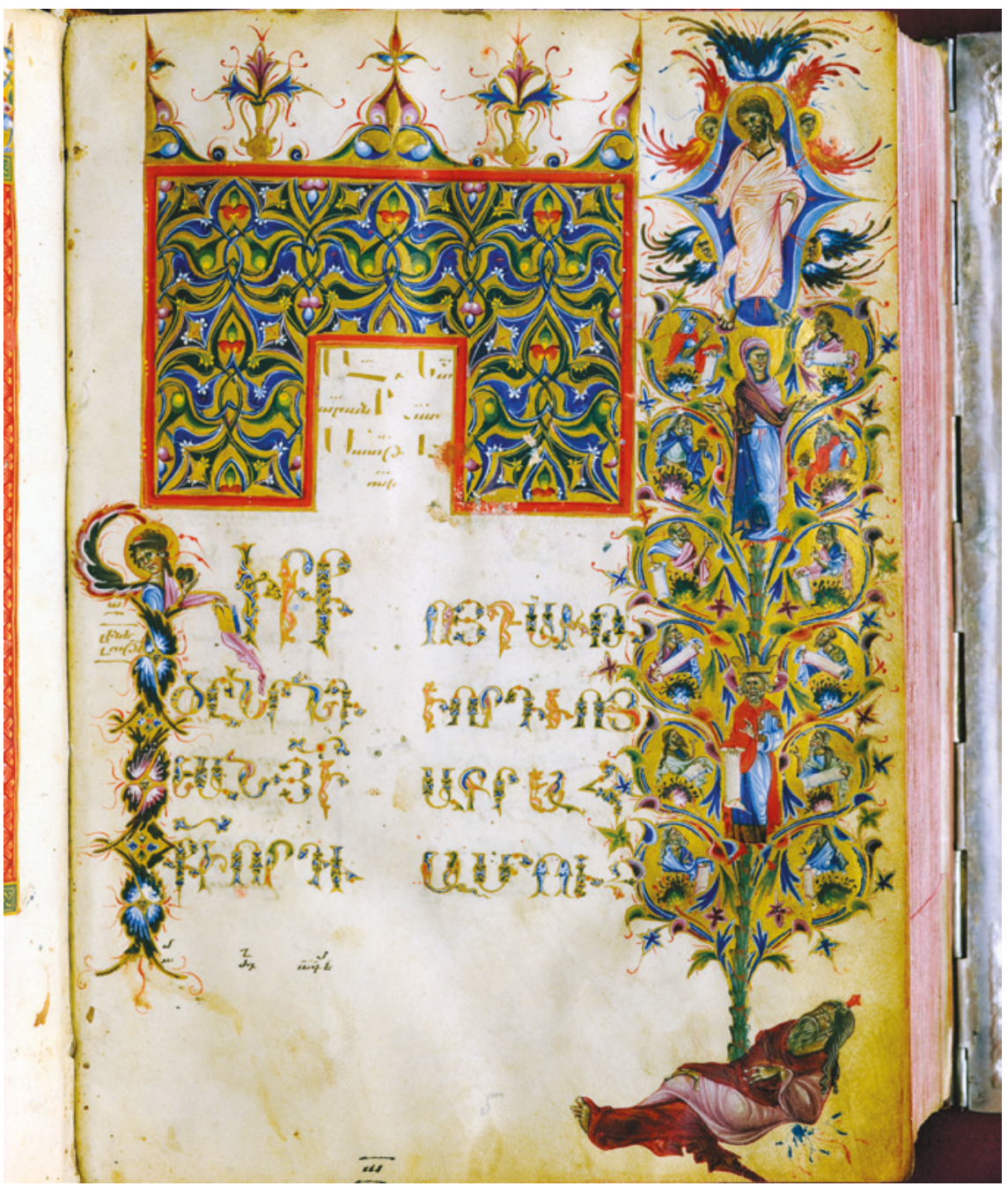

FIGURE 3.7 Tree of Jesse. Gospel, 13th century, Jerusalem, Armenian Patriarchate 2568, fol. $5 \mathrm{r}$ PHOTOGRAPH BY HRAIR HAWK KHATCHERIAN 


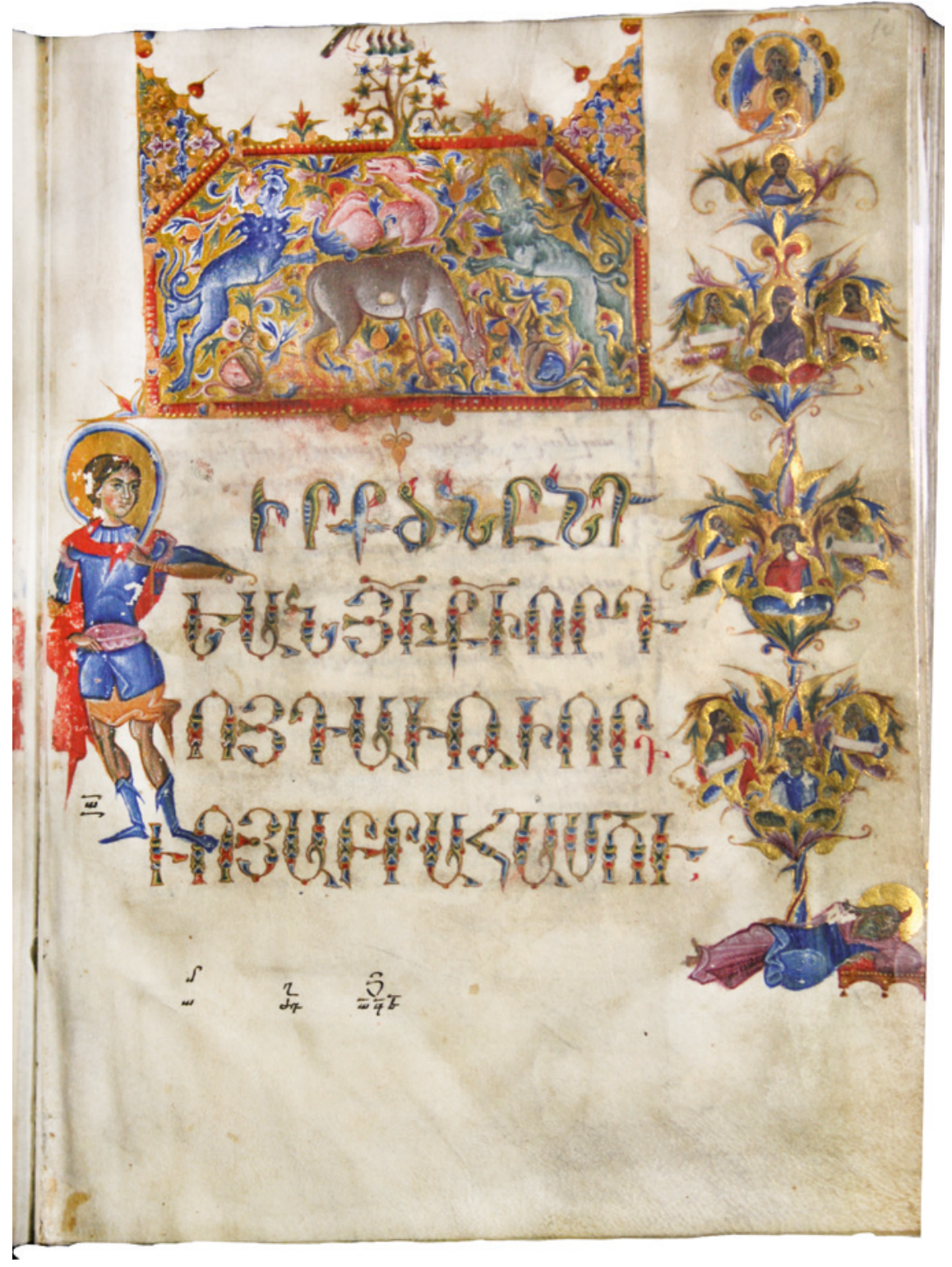

FIGURE 3.8 Tree of Jesse. Gospel, 13th century, Yerevan, Matenadaran 7651 , fol. 1or WITH KIND PERMISSION OF MATENADARAN 


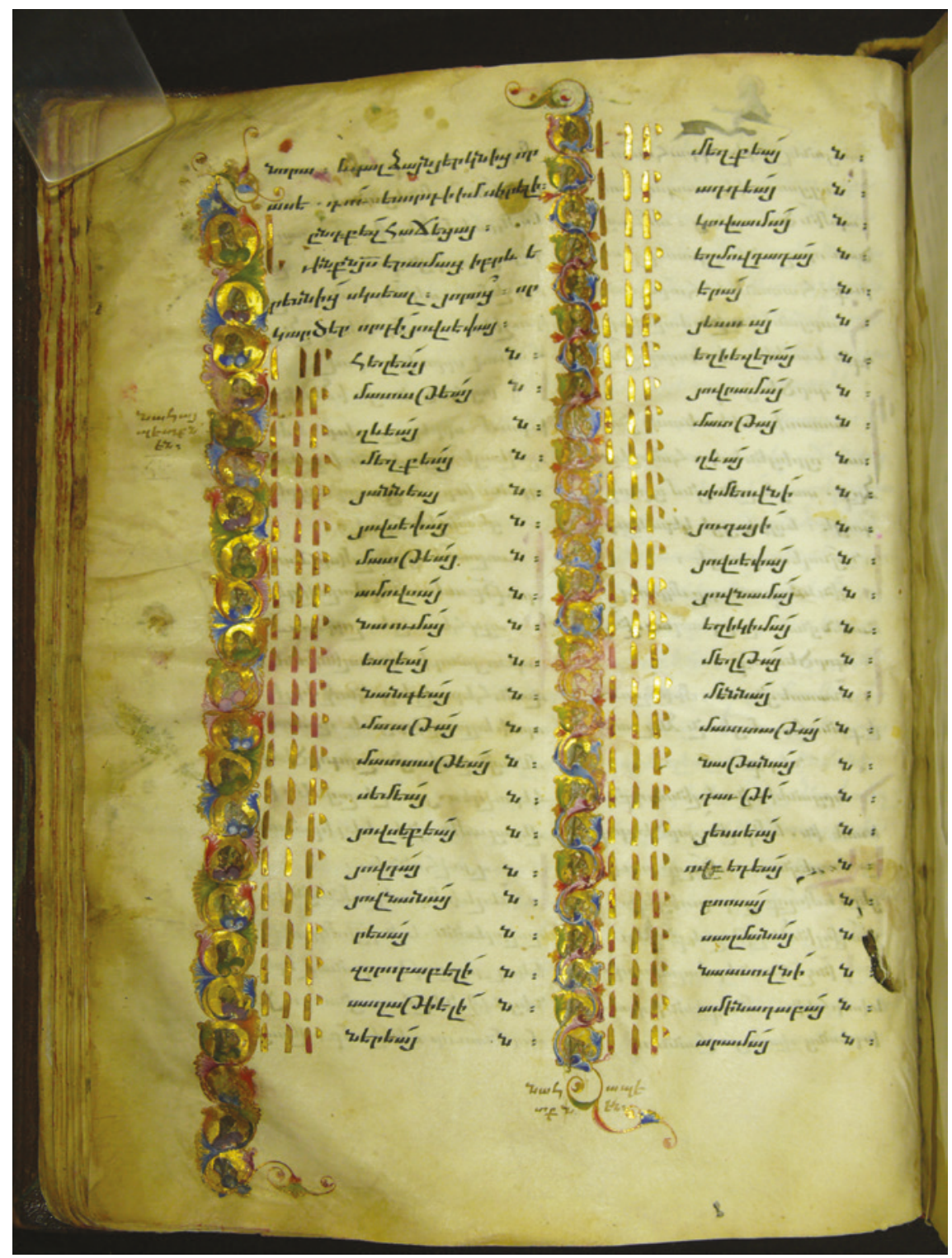

FIGURE 3.9 Ancestors of Christ. Het'um's Lectionary (1286), Yerevan, Matenadaran 979, fols $44 \mathrm{~V}$ 


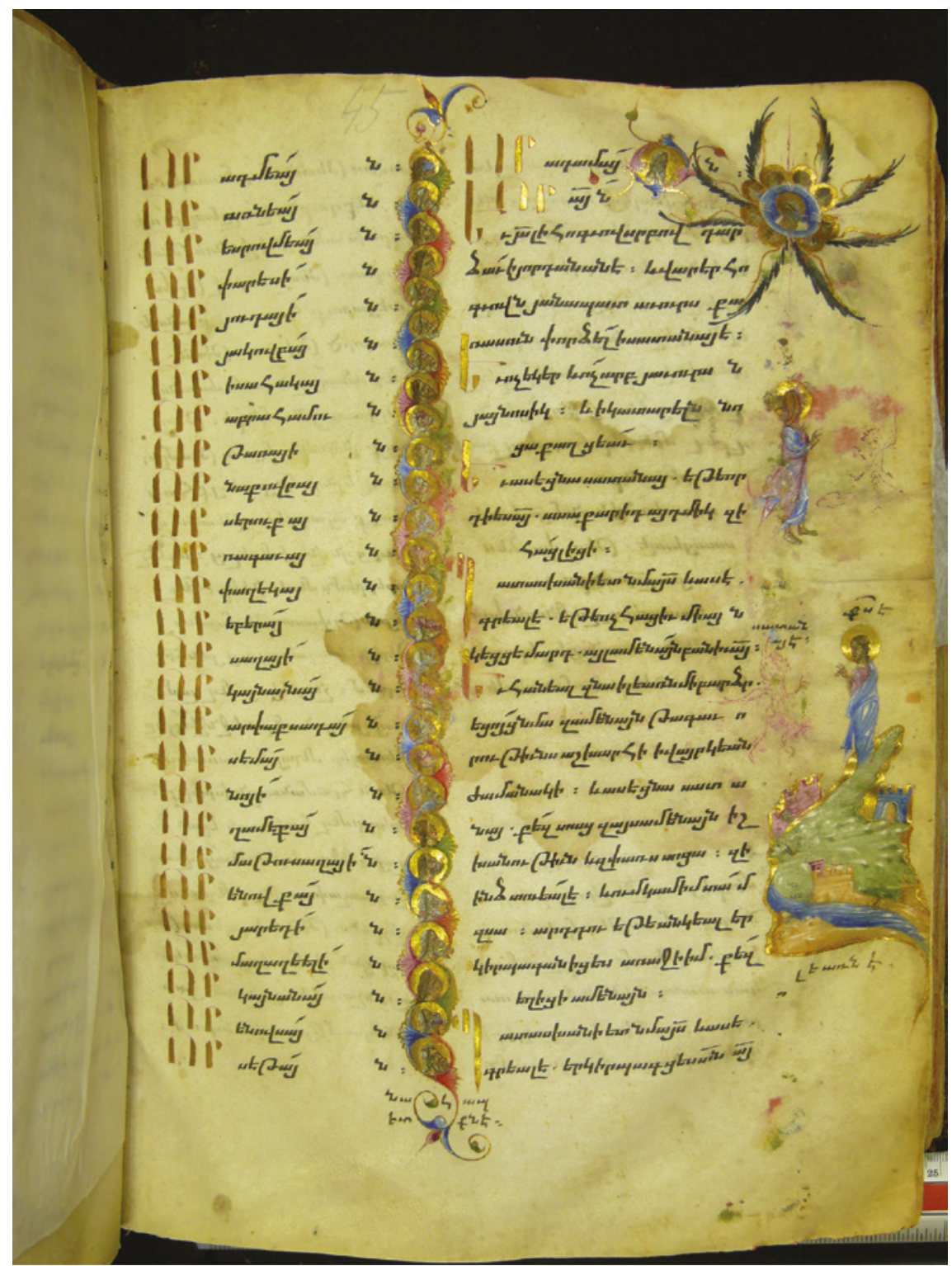

FIGURE 3.9 Ancestors of Christ. Het'um's Lectionary (1286), Yerevan, Matenadaran 979, fols. $45^{\mathrm{r}}$

WITH KIND PERMISSION OF MATENADARAN 


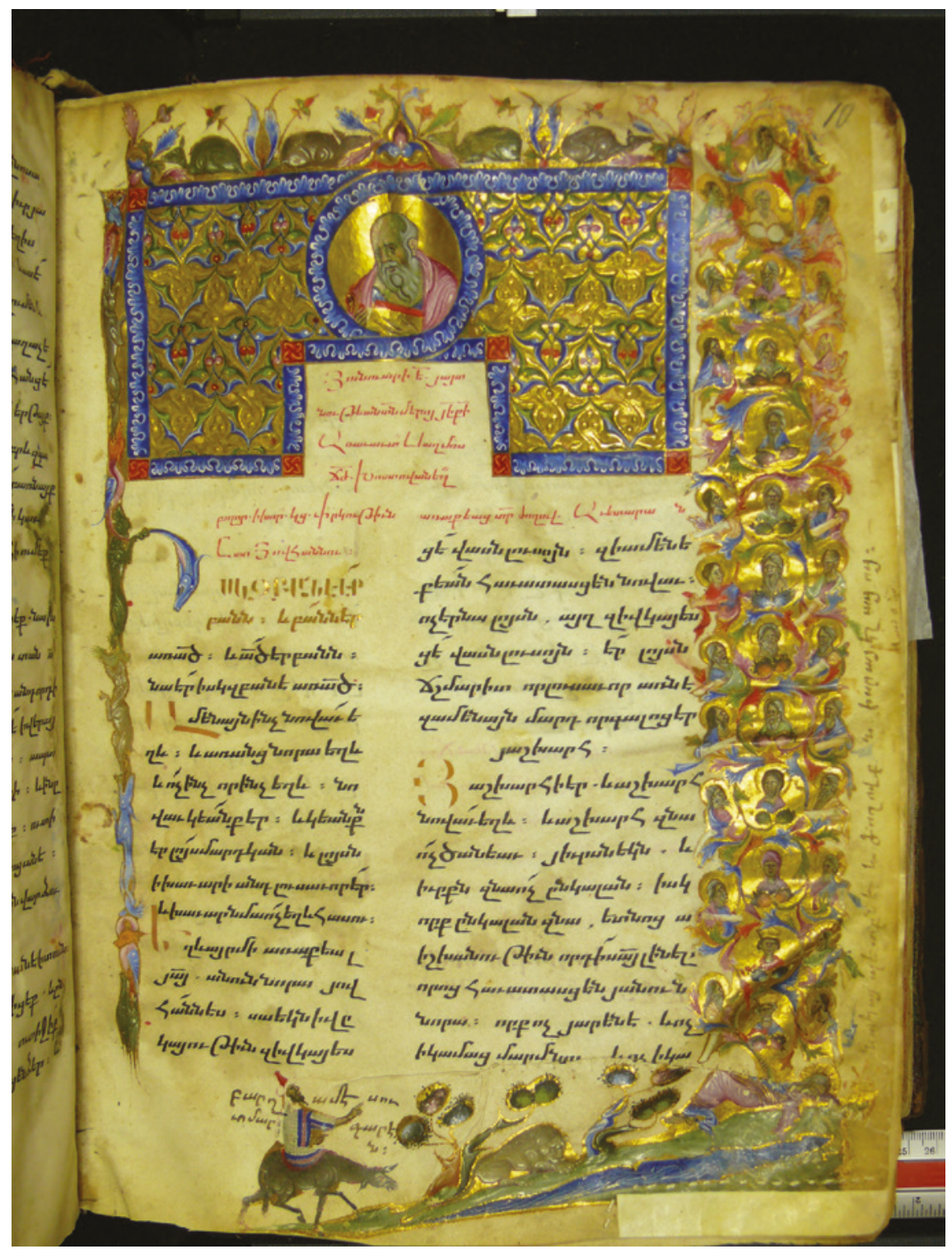

FIGURE 3.10 Tree of Jesse. Het'um's Lectionary (1286), Yerevan, Matenadaran 979, fol. 1or WITH KIND PERMISSION OF MATENADARAN 


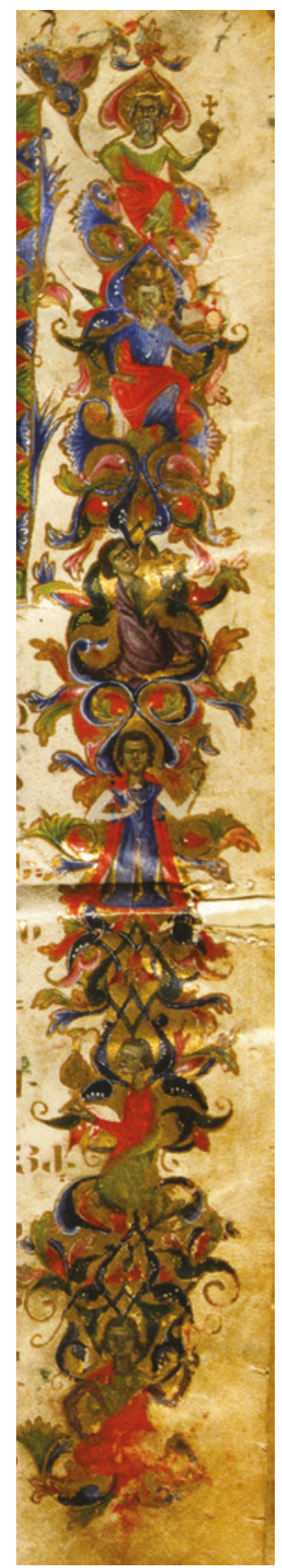

FIgURE 3.11 Royal Portrait in Het'um's Lectionary (1286). Yerevan, Matenadaran 979, fol. 7r WITH KIND PERMISSION OF MATENADARAN 


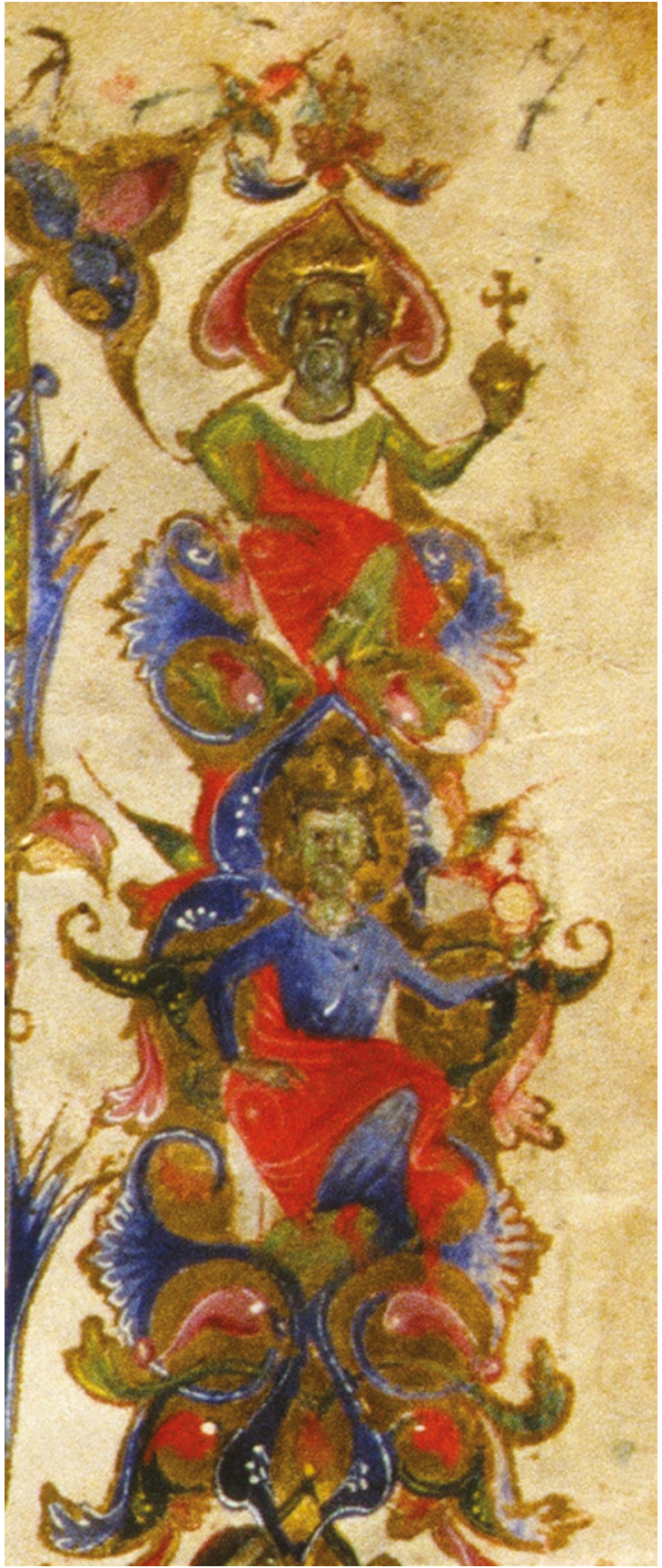

FIGURE 3.12 A) Royal Portrait in Het'um's Lectionary, detail 


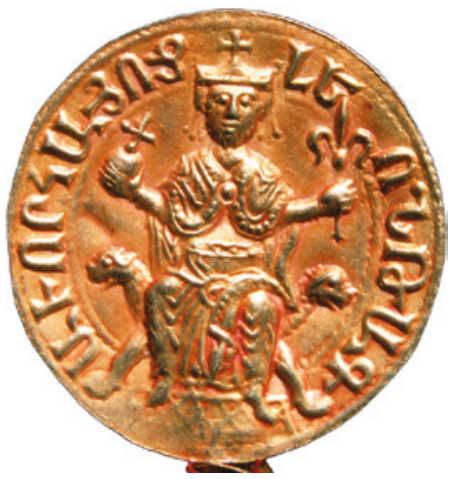

FIGURE 3.12 B) Gold Seal of Lewon I

FROM: C. MUTAFIAN, L'ARMÉNIE DU LEVANT, VOL. 2, FIGURE. 97 